\title{
Vitamin C-Sources, Physiological Role, Kinetics, Deficiency, Use, Toxicity, and Determination
}

\author{
Martin Doseděl ${ }^{1}\left(\right.$ D, Eduard Jirkovský ${ }^{2}$, Kateřina Macáková ${ }^{3}$, Lenka Kujovská Krčmová ${ }^{4,5}$, Lenka Javorská ${ }^{5}$,

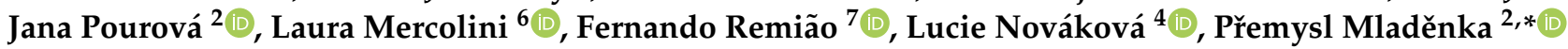 \\ and on behalf of The OEMONOM ${ }^{\dagger}$
}

check for

updates

Citation: Doseděl, M.; Jirkovský, E.; Macáková, K.; Krčmová, L.K.; Javorská, L.; Pourová, J.; Mercolini, L.; Remião, F.; Nováková, L.; Mladěnka, P.; Vitamin C-Sources, Physiological Role, Kinetics, Deficiency, Use, Toxicity, and Determination. Nutrients 2021, 13, 615. https://doi.org/ $10.3390 /$ nu13020615

Academic Editor: Roberto Iacone

Received: 30 December 2020

Accepted: 8 February 2021

Published: 13 February 2021

Publisher's Note: MDPI stays neutral with regard to jurisdictional claims in published maps and institutional affiliations.

Copyright: (C) 2021 by the authors Licensee MDPI, Basel, Switzerland. This article is an open access article distributed under the terms and conditions of the Creative Commons Attribution (CC BY) license (https:/ / creativecommons.org/licenses/by/ $4.0 /)$.
1 Department of Social and Clinical Pharmacy, Faculty of Pharmacy, Charles University, 50005 Hradec Králové, Czech Republic; martin.dosedel@faf.cuni.cz

2 Department of Pharmacology and Toxicology, Faculty of Pharmacy, Charles University, 50005 Hradec Králové, Czech Republic; JirkovskyE@faf.cuni.cz (E.J.); pourova@faf.cuni.cz (J.P.)

3 Department of Pharmacognosy, Faculty of Pharmacy, Charles University, 50005 Hradec Králové, Czech Republic; macakovak@faf.cuni.cz

4 Department of Analytical Chemistry, Faculty of Pharmacy, Charles University, 50005 Hradec Králové, Czech Republic; KRCML1AA@faf.cuni.cz (L.K.K.); novakoval@faf.cuni.cz (L.N.)

5 Department of Clinical Biochemistry and Diagnostics, University Hospital Hradec Králové, 50005 Hradec Králové, Czech Republic; lenka.javorska@fnhk.cz

6 Research group of Pharmaco-Toxicological Analysis (PTA Lab), Department of Pharmacy and Biotechnology (FaBiT), Alma Mater Studiorum-University of Bologna, 40126 Bologna, Italy; laura.mercolini@unibo.it

7 UCIBIO-REQUIMTE, Laboratory of Toxicology, Biological Sciences Department, Faculty of Pharmacy, University of Porto, 4050-313 Porto, Portugal; remiao@ff.up.pt

* Correspondence: mladenkap@faf.cuni.cz; Tel.: +420-495067295

+ Listed at the end of Acknowledgments.

Abstract: Vitamin C (L-ascorbic acid) has been known as an antioxidant for most people. However, its physiological role is much larger and encompasses very different processes ranging from facilitation of iron absorption through involvement in hormones and carnitine synthesis for important roles in epigenetic processes. Contrarily, high doses act as a pro-oxidant than an anti-oxidant. This may also be the reason why plasma levels are meticulously regulated on the level of absorption and excretion in the kidney. Interestingly, most cells contain vitamin $\mathrm{C}$ in millimolar concentrations, which is much higher than its plasma concentrations, and compared to other vitamins. The role of vitamin $C$ is well demonstrated by miscellaneous symptoms of its absence-scurvy. The only clinically well-documented indication for vitamin $C$ is scurvy. The effects of vitamin $C$ administration on cancer, cardiovascular diseases, and infections are rather minor or even debatable in the general population. Vitamin $C$ is relatively safe, but caution should be given to the administration of high doses, which can cause overt side effects in some susceptible patients (e.g., oxalate renal stones). Lastly, analytical methods for its determination with advantages and pitfalls are also discussed in this review.

Keywords: ascorbic acid; antioxidant; prooxidant; scurvy; oxalate; epigenetic

\section{Introduction}

Vitamin C is known as L-ascorbic acid since it was observed as the factor needed for the treatment of scurvy (in Latin scorbutus, hence, "a-scorbutus"). Since the terms "fatsoluble vitamin A" and "water-soluble vitamin B" were already in use, the term vitamin C was coined. In general, the term also includes its oxidized form, L-dehydroascorbic acid, which can easily be converted into L-ascorbic acid in the human body.

In contrast to most of the vertebrates, guinea pigs, bats, passeriform birds, and primates, including humans, lack L-gulono-1,4-lactone oxidase, and, hence, cannot synthesize 
vitamin C. They are, therefore, fully dependent on vitamin C intake from the diet [1-3]. Vitamin $C$ is very popular among the general population mainly due to its antioxidant properties. Its role is, however, more extensive and will be discussed in this review. This is reflected by the body content of vitamin $C$ that is unusually high compared to other vitamins. The human body was suggested to contain about $1.5 \mathrm{~g}$ of vitamin $\mathrm{C}$, which corresponds to around $20 \mathrm{mg} / \mathrm{kg}$. The daily need in humans is hardly or at all assessable since it depends on many factors, including physiological status, stress, and diseases. Recommendations differ substantially from 40 to $120 \mathrm{mg}$ /day in various countries. This dose represents the assessment of the normal need for vitamin $C$ in humans. In pregnant women, an additional $5-10 \mathrm{mg}$ is recommended ( $25 \mathrm{mg}$ in lactating mothers) [3-6]. The total daily dose of about $10 \mathrm{mg}$ is sufficient to prevent scurvy in the general population [3].

This review is devoted to the biological aspects of L-ascorbic acid (Figure 1A). Its epimer erythorbic acid (Figure 1B, also known as isoascorbic acid or D-araboascorbic acid), which is used as a food additive, and its enantiomer D-ascorbic acid (Figure 1C) are also partly active as vitamin C. However, they are only poorly retained by tissues and are more rapidly excreted from the human body [7-10].
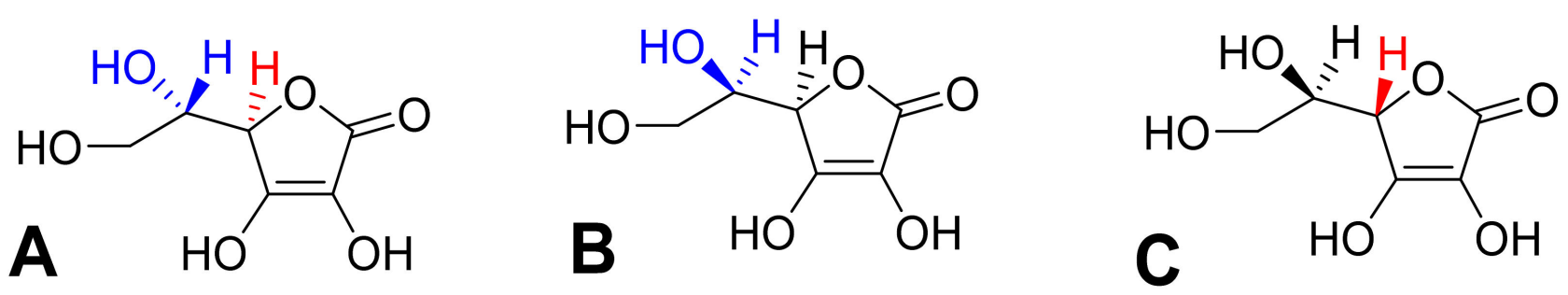

Figure 1. Optical isomers of vitamin C. (A) L-ascorbic acid, (B) erythorbic acid, and (C) D-ascorbic acid. Differences are shown in red and blue.

\section{Sources}

In contrast to many other vitamins, the content of vitamin $C$ in various foods is, in general, relatively high (10-100 mg/100 g), and, in some cases, it reaches units of grams per $100 \mathrm{~g}$ of fresh weight. This is possibly related to the fact that vitamin $\mathrm{C}$ is formed from sugars, which are common compounds in different organisms. So far, the synthesis of vitamin $C$ was documented in all plant species, including algae and photosynthetic protists [1]. In plants, L-ascorbic acid is responsible for three main functions: an enzyme cofactor, a radical scavenger, and a donor/acceptor in electron transport either in the plasma membrane or in the chloroplasts, besides other minor functions [11]. Currently, most of the daily intake of vitamin $C$ comes from fruits and vegetables, which, in many countries, unlike in the past, are available throughout the year. A large part is also obtained from potatoes and soft drinks, including juices. Although most vertebrates are able to synthesize vitamin $C$, animal sources do not contribute much to the intake because the content of vitamin C in them is generally low, except for livestock livers, which are consumed minimally, and some fish eggs. However, they are of the utmost importance to nations living in subarctic areas [12,13]. Besides plants and animals, fungi are also capable of biosynthesis of vitamin C. However, its content in both wild and cultivated fungi is generally very low [14-16].

Several fruits from different parts of the world, including kakadu plum from Australia, camu-camu, and acerola from South America, are the richest vitamin $C$ sources (Table 1) [17-19]. In Europe and Asia, rose hips and sea buckthorn are considered the richest sources of this vitamin $[20,21]$. Most people get a large portion of their daily vitamin $\mathrm{C}$ intake through regular consumption of fruits and fruit juices. The species composition varies by region. Globally, star fruit, guava, black currant, kiwi, and strawberry are good sources. Compared to the richest sources of the vitamin, citruses contain a significantly lower but sufficient amount of vitamin C [22-25]. Considering vegetables, cruciferous vegetables, especially broccoli, kale, and peppers, are also rich sources [26,27]. The content 
of vitamin C in fermented cabbage (sauerkraut) is even higher than in most fresh vegetables [28]. In contrast, potatoes have a relatively low vitamin C content but play an important role in its intake because they are consumed in large quantities [29]. Notwithstanding the fact that they are consumed boiled, they are a suitable source of vitamin C. A single serving of potatoes offers 5-40 $\mathrm{mg}$ of vitamin C. In recent years, they have accounted for an average of $8 \%$ of the total daily intake of vitamin $C$ in European countries $[3,12]$. Fresh aromatic herbs (coriander, parsley, chives), which are a frequent part of vegetable salads, also make a significant contribution to their overall vitamin $C$ content [30]. Algae belonging to different taxonomic groups are also not negligible sources. Their vitamin $\mathrm{C}$ content is in the tens of $\mathrm{mg}$ by $100 \mathrm{~g}$ [31]. As can be seen from Table 1, the vitamin C content of individual plant species is highly variable due to many factors, including place of cultivation, harvesting time (ripening stage), weather conditions, latitude, genotype, agrotechnology, analytical method used for determination, and processing [24,32-35].

Aqueous vitamin $C$ solutions are unstable since oxygen and other oxidizing agents, high $\mathrm{pH}$, high temperature, and metal ions cause its decomposition. Long-term cooking and, in particular, boiling with a large amount of water results in leaching of vitamin $C$ into the water and, hence, markedly decreases the vitamin C content in food. Even blanching leads to relatively large losses of vitamin C. Surprisingly, frying can retain a sufficient amount of the vitamin. However, steaming or boiling in a small amount of water seem to be more gentle ways in relation to vitamin $C$ preservation. Losses occur even if all external factors are eliminated to a minimum because oxidation reactions take place inside the material due to the presence of ascorbic acid oxidase. Thus, the ideal processing method is the rapid thermal inactivation of the enzyme with a minimal amount of water followed by rapid cooling. The temperature also has a large impact on storage stability. With increasing temperature, more significant losses occur. However, during long-term storage, the amount of vitamin C decreases significantly even if conditions under which only small losses occur during short-term storage are maintained. Post-harvest losses are mainly due to an enzymecatalyzed oxidation reaction, which degree depends especially on $\mathrm{pH}$, material integrity, and temperature. Summing up, the gentlest way to preserve fruits and vegetables for their content of vitamin $C$ for a longer time is deep-freezing [3,5,11,36-38].

Industrially, most of the L-ascorbic acid is currently produced by two fermentation processes requiring several chemically-based steps: the Reichstein process and the two-step fermentation process. The Reichstein process is based on the catalytic hydrogenation of D-glucose to D-sorbitol and subsequent bioconversion to L-sorbose using Gluconobacter spp., which is followed by oxidation of L-sorbose to 2-keto-L-gulonic acid. This is rearranged to L-ascorbic acid by lactonization. In the second production process, the chemical production of 2-keto-L-gulonic acid from L-sorbose is replaced by bioconversion using various bacteria [39]. Although the bioavailability of biotechnologically prepared and plant(food)-derived vitamin $C$ seems to be comparable as described in the absorption section, many people prefer vitamin $C$ of natural origin, including both food and food supplements [40]. The richest sources of vitamin C, such as kakadu plum, camu-camu, acerola, rosehips, and sea buckthorn fruits, are mainly used to produce food supplements (Table 1).

Table 1. Vitamin C content in selected fruits, vegetables, and medicinal plants.

\begin{tabular}{|c|c|c|c|c|}
\hline Latin Name & Family & Vernacular Name & Vitamin C Content & References \\
\hline \multicolumn{5}{|l|}{ Fruits } \\
\hline Terminalia ferdinandiana Exell & Combretaceae & Kakadu plum & $1360-22,490^{b}$ & {$[17,41]$} \\
\hline Myrciaria dubia (Kunth) McVaugh & Myrtaceae & Camu-camu & $850-5000^{a}$ & {$[18,42]$} \\
\hline Malpigia emarginata DC. & Malpighiaceae & Acerola & $820-4023^{\text {a }}$ & {$[19,34]$} \\
\hline Averrhoa bilimbi L. & Oxalidaceae & Bilimbi & $2698^{c}$ & [22] \\
\hline Averrhoa carambola L. & Oxalidaceae & Star fruit & $1626^{c}$ & [22] \\
\hline Psidium guajava L. & Myrtaceae & Guava & $89-980^{a}$ & {$[18,23,43]$} \\
\hline Anacardium occidentale L. & Anacardiaceae & Cashew apple & $555^{\mathrm{a}}$ & [25] \\
\hline Phyllanthus emblica L. & Phyllanthaceae & Emblic & $469^{\mathrm{a}}$ & [35] \\
\hline
\end{tabular}


Table 1. Cont.

\begin{tabular}{|c|c|c|c|c|}
\hline Latin Name & Family & Vernacular Name & Vitamin C Content & References \\
\hline Ribes nigrum $\mathrm{L}$. & Grossulariaceae & Black currant & $\begin{array}{l}148-310^{\mathrm{a}} \\
60-250^{\mathrm{d}}\end{array}$ & $\begin{array}{l}{[24]} \\
{[32]}\end{array}$ \\
\hline $\begin{array}{c}\text { Actinidia deliciosa (A.Chey.)C.F.Liang } \\
\text { et A.R.Ferguson }\end{array}$ & Actinidiaceae & Kiwi & $60-78^{a}$ & {$[11,25]$} \\
\hline Fragaria virginiana Duchesne & Rosaceae & Strawberry & $65^{\mathrm{a}}$ & [25] \\
\hline Citrus $\mathrm{x}$ sinensis (L.)Osbeck. & Rutaceae & Orange & $41-58^{a}$ & {$[11,25,44]$} \\
\hline Citrus limon (L.)Osbeck. & Rutaceae & Lemon & $30^{d_{31}}{ }^{a}$ & {$[44,45]$} \\
\hline Citrus reticulata Blanco & Rutaceae & Common mandarin & $27^{\mathrm{a}}$ & [25] \\
\hline Malus domestica Borkh. & Rosaceae & Apple & $11-35^{\mathrm{a}}$ & [46] \\
\hline $\begin{array}{c}\text { Pyrus communis L. } \\
\text { Vegetables }\end{array}$ & Rosaceae & Pear & $7-29^{\text {a }}$ & [46] \\
\hline Brassica oleracea var. italica Plenck. & Brassicaceae & Broccoli & $25-130^{a}$ & [26] \\
\hline $\begin{array}{c}\text { Brassica oleracea var. acephala } \\
\text { (DC.)Alef. }\end{array}$ & Brassicaceae & Kale & $51-120^{a}$ & [26] \\
\hline Capsicum annuum L. & Solanaceae & Pepper & $107-154^{a}$ & [27] \\
\hline Solanum tuberosum L. & Solanaceae & Potato & $8-30^{a}$ & {$[11,29]$} \\
\hline $\begin{array}{l}\text { Solanum lycopersicum } \mathrm{L} \text {. } \\
\text { Fermented vegetable }\end{array}$ & Solanaceae & Tomato & $9-17^{\mathrm{a}}$ & {$[47,48]$} \\
\hline $\begin{array}{l}\text { Brassica oleracea var. capitata (L.)Alef. } \\
\text { Medicinal plants and herbs }\end{array}$ & Brassicaceae & Sauerkraut & $103-277^{b}$ & [28] \\
\hline Hippophä̈ rhamnoides L. & Eleagnaceae & Sea buckthorn & $70-1320^{\mathrm{d}}$ & {$[20,33]$} \\
\hline Rosa canina L. & Rosaceae & Rosehip & $40-360^{a}$ & {$[21,49]$} \\
\hline Coriandrum sativum $\mathrm{L}$. & Apiaceae & Coriander & $48-98^{\mathrm{a}}$ & {$[30,50]$} \\
\hline Allium schoenoprasum L. & Amaryllidaceae & Chives & $93^{\mathrm{a}}$ & {$[30]$} \\
\hline Petroselinum crispum (Mill.)Nym. & Apiaceae & Parsley & $59^{a}$ & {$[30]$} \\
\hline
\end{tabular}

$\mathrm{mg} / 100 \mathrm{~g}$ of a fresh weight, ${ }^{\mathrm{b}}$ dry weight, ${ }^{\mathrm{c}}$ juice, $\mathrm{mg} / 100 \mathrm{~mL}$ of ${ }^{\mathrm{d}}$ juice.

\section{Kinetics of Vitamin C}

\subsection{Absorption}

The absorption of vitamin $C$ takes place mostly in the distal ileum. The transport to enterocytes is mediated by SVCT1 (sodium-dependent vitamin C transporter 1, solute carrier of the family of ascorbate transporters, SLC23A1, Figure 2A). It is, therefore, saturable and sodium dependent. The Michaelis constant $K_{m}$, i.e., the concentration of vitamin $C$ transported by half of the maximal transport velocity, was reported to be in a wide range from 10 to $200 \mu \mathrm{M}$, suggesting a large capacity to absorb dietary vitamin C. Its activity is highest at a neutral $\mathrm{pH}$. It drops markedly with increasing acidity [51-54]. Some passive diffusion in the gastrointestinal tract (GIT) cannot be fully excluded since vitamin $C$ is present in the non-ionized form at a low $\mathrm{pH}$. This can be supported by the fact that its isomer, erythorbic acid, which is a poor substrate of SVCT1, reaches similar plasma concentrations as vitamin C [52]. Based on the saturable mechanism of vitamin $C$ transport via SVCT1, it is not surprising that the absorption is not linear. The bioavailability decreases with an increasing dose being 100\% in a low dose of $200 \mathrm{mg}$ and dropping to an average of $73 \%$ at a dose of $500 \mathrm{mg}$ and to approximately $50 \%$ in the dose of $1.25 \mathrm{~g}$ [55]. Higher doses have even lower bioavailability [56]. Later, a more sophisticated bioavailability calculation suggested slightly different values [57] (see Figure 3). There is a discussion whether synthetic or pure vitamin $C$ has better or lower bioavailability than dietary vitamin C. Some suggestions were coming from experimental studies that diet rich in flavonoids can improve it, but the data are inconclusive [40]. This is likely due to the fact that vitamin $\mathrm{C}$ has high bioavailability. Hence, minor changes in this parameter are not easily detectable considering physiological inter-individual variability, which can also be seen in Figure 3. 

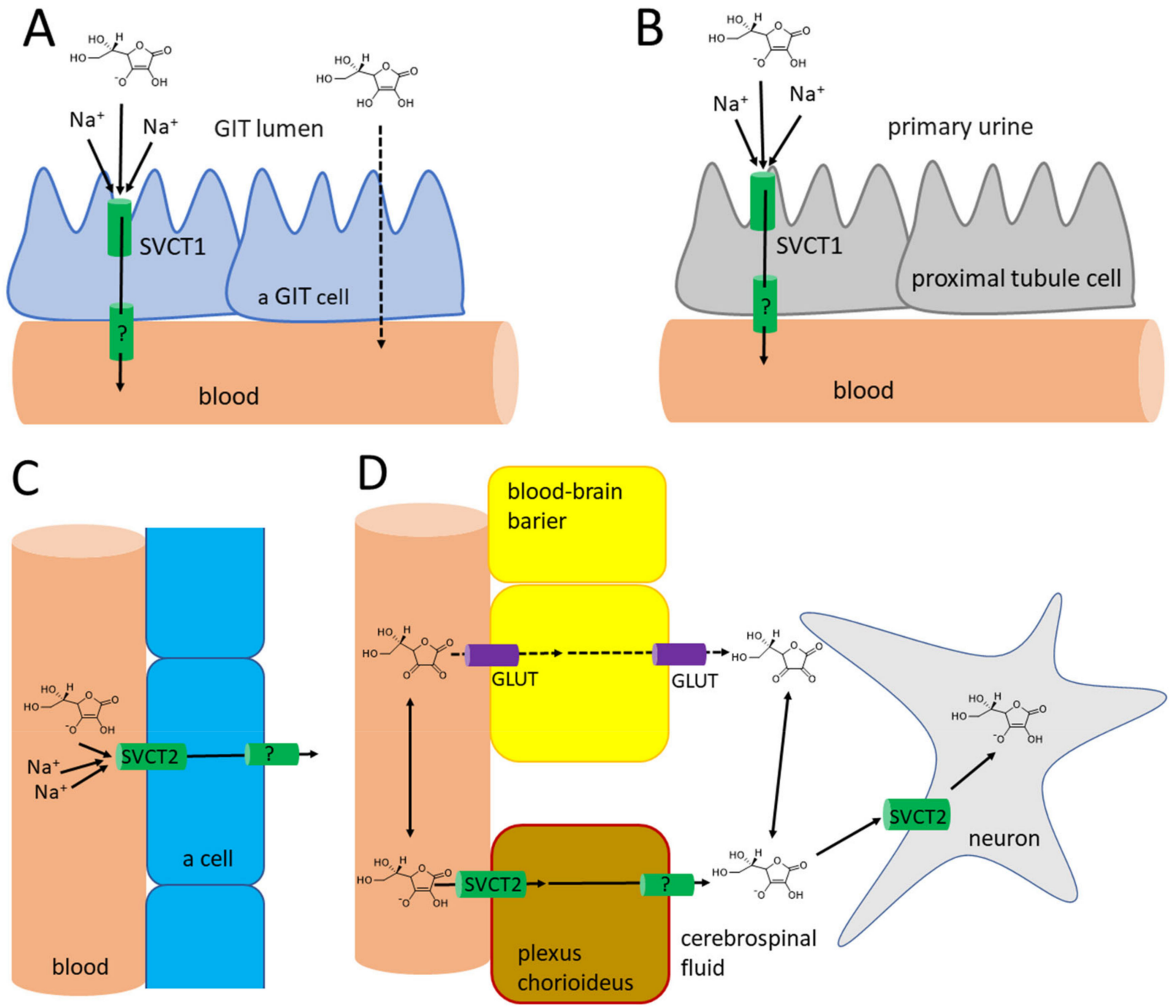

Figure 2. Vitamin $\mathrm{C}$ kinetics in the human body. (A): Absorption in the gastrointestinal tract. In the distal ileum, the absorption of ascorbate is mediated via SVCT1, while in the upper parts of the GIT, where pH is lower, the passive diffusion of non-ionized ascorbic acid is also possible. Absorption of dehydroascorbic acid does not seem to contribute significantly and is not shown. (B): reabsorption of vitamin $C$ through the proximal tubules to the blood. Passive diffusion is also possible in acidic urine, likely in other parts of the urinary tract, but it does not seem to contribute significantly to vitamin $\mathrm{C}$ reabsorption and is, hence, not shown. (C): Distribution of vitamin C to most cells. (D): Distribution of vitamin $C$ to the neurons. There are no specific transporters for ascorbate in the blood-brain barrier. Hence, the only possible way is the uptake and release of vitamin C in the form of dehydroascorbic acid via glucose transporters (GLUT). This transport is likely not the major contributor of vitamin $\mathrm{C}$ distribution to the brain (see corresponding part of the article). Contrarily, in the choroid plexus, the SVCT2 is expressed and this seems to be the major pathway for vitamin C kinetics to the brain. Neurons are also expressing SVCT2.

The oxidized form of vitamin C, dehydroascorbic acid, is absorbed likely through glucose transporters, and glucose decreases absorption of dehydroascorbic acid. In any case, the contribution of dehydroascorbic acid to the total vitamin $C$ absorption is probably low [52].

The efflux of ascorbic acid from GIT cells to the circulation is likely mediated by a transporter, but its identity is currently unknown. Dehydroascorbic acid can be again transported through the basolateral membrane of these cells by glucose transporters [52]. In general, vitamin $\mathrm{C}$ absorption is relatively slow, as maximal plasma levels are reached after $2-4 \mathrm{~h}[6,8,40,58]$. 


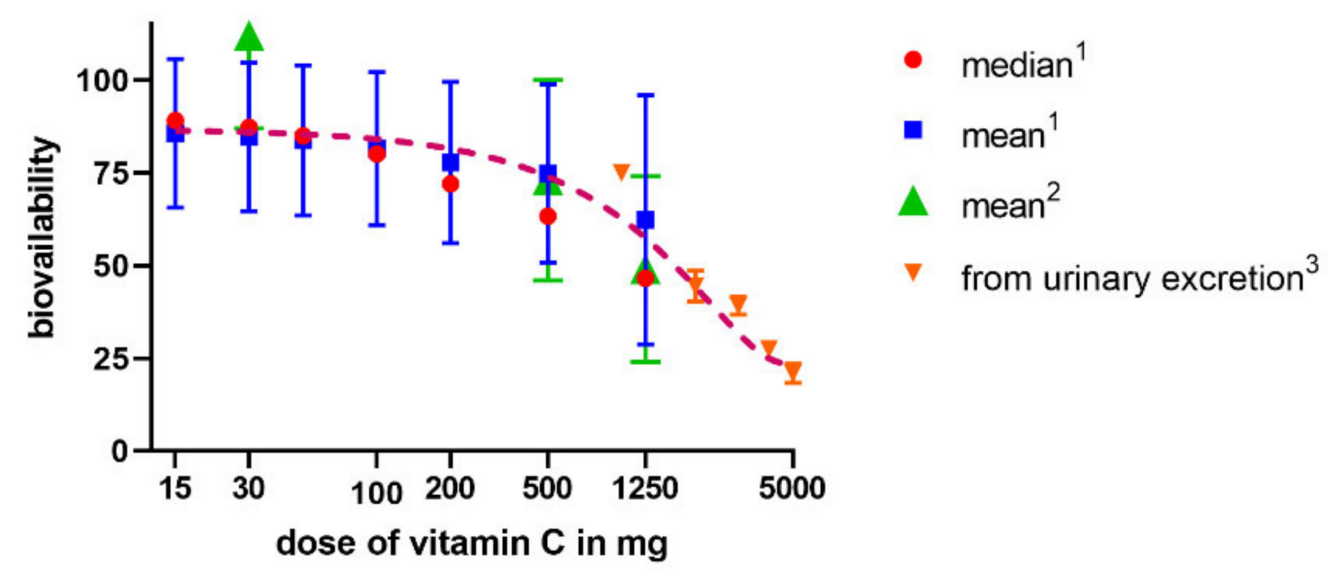

Figure 3. Relationship between a dose of vitamin $C$ and bioavailability in humans. The data are from three studies_- ${ }^{1}$ Graumlich et al. 1997 [57], ${ }^{2}$ Levine et al., 1996 [55], and ${ }^{3}$ Hornig et al., 1980 [56].

\subsection{Distribution and Metabolism}

The average plasma levels of vitamin $C$ in a healthy adult population is between 40 and $65 \mu \mathrm{M}$. There is no difference between serum and plasma [59-63]. The levels of vitamin $C$ fluctuate with age. They are highest in the category of 6 to 11 years old and then gradually decrease. There is, however, an increase in the population over 60 years old in both men and women [61]. Women have, in general, higher plasma levels than men [61]. The maximal steady-state, long-term vitamin $C$ plasma levels achievable by oral administration are 70-85 $\mu \mathrm{M}[5,64]$. The plasma levels increase to this plateau concentration up to doses of about 200-400 mg daily. Higher doses increase plasma levels only minimally $[55,65,66]$. Concentrations up to $220 \mu \mathrm{M}$ can also be reached for a short time, but this requires a maximum tolerable dose of $3 \mathrm{~g}$ every 4 hours [64]. It is well known that smoking affects vitamin $C$ plasma levels negatively [60,61]. Smoking decreases the plasma level of vitamin $C$ on an average by $25-50 \%$ [52,61,63]. Ex-smoking seems to slightly decrease the levels as well $[52,60]$. These lower plasma levels can be at least partly accounted to the increased oxidative stress caused by smoke. The need for vitamin $C$ in smokers is higher, but the available studies suggested different recommendations ranging from 35 to $200 \mathrm{mg}$ of additional vitamin C/day needed for smokers [52]. The plasma levels of dehydro-ascorbic acid are very low in healthy humans, while that of an ascorbyl radical are undetectable $[6,53,54,62,67]$. Vitamin $C$ is not bound to plasma proteins [62].

The $\mathrm{pKa}$ of ascorbic acid is 4.1-4.2. Hence, it is present completely as a monoanionascorbate at the physiological $\mathrm{pH}[1,2,4,68]$. This form cannot cross the membranes directly. For this reason, transporters are crucial players in the pharmacokinetics of vitamin C. Vitamin C is taken up by the cells via SVCT2 (SLC23A2, Figure 2C), which is a close analogue of SVCT1 with which it shares $65 \%$ sequence homology. SVCT2 is largely expressed in most organs. The expression of SVCT1 is much more limited. In addition to the intestine, it is localized in the liver, lung, skin, ovary, prostate, and kidney. In mice, the absence of SVCT2 leads to the absence of the vitamin in the lungs, but the liver is not affected. Like SVCT1, SVCT2-mediated transport is unidirectional and uses an electrochemical sodium gradient. Two sodium ions are needed for the transport of vitamin $C$ by both transporters. SVCT2 has a 2-10 fold higher affinity to vitamin C when compared to SVCT1. However, the $V_{\max }$ is apparently lower. This suggests a lower capacity to transport vitamin $C$, but with higher sensitivity, i.e., the transport is also working in lower concentrations of vitamin C. This agrees with the physiological need for a higher capacity of SVCT1 to transport vitamin C from the diet and the function of SVCT2 to provide vitamin C to the cells even in the presence of low plasma vitamin C [51-54,69,70]. SVCT2 enables a considerable plasmatissues concentration gradient. The intracellular levels of vitamin $C$ are much higher than plasma levels. Vitamin C reaches a concentration between $0.5-5 \mathrm{mM}$ in most cells with the exception of erythrocytes, which do not express SVCT2, and, hence, their cytosolic 
levels reflect plasma levels and are about $50 \mu \mathrm{M}[52,55,68,71]$. In contrast to maximal plasma levels reported above, the maximal concentration in different types of white blood cells was achieved by a dose of $100 \mathrm{mg}$ daily. Higher doses in men did not increase this intracellular level substantially [55]. The possible reason can be the saturable kinetics of active transport by SVCT2 with $\mathrm{K}_{\mathrm{m}}$ of approximately $60-70 \mu \mathrm{M}$, which are the approximate plasma levels associated with 100-mg daily dosing [5]. This was not confirmed in women where the saturable doses were 200-400 mg daily, matching with doses producing maximal steady-state plasma levels [66]. Physiologically high levels (2-10 mM) are found in neurons and endocrine cells (particularly, the adrenal and pituitary gland), which is apparently related to the synthesis of hormones and neuro-mediators described below $[4,6,8,72,73]$. Vitamin $C$ has little tendency to exit the cells likely due its hydrophilic nature and negative charge at a physiological $\mathrm{pH}$ [73]. In extracellular fluid, the concentrations are slightly higher than in plasma, but, in general, they reflect plasma levels [67].

Dehydroascorbic acid does not resemble glucose, but it forms bicyclic hemiketal (Figure 4A,B), which resembles glucose [74,75] and has high affinity for glucose transporters GLUT1 and GLUT3 (GLUT4 can be involved, but GLUT2 and GLUT5 are not) [54]. These transporters mediate facilitated diffusion and are, therefore, bidirectional. Since the concentration of dehydroascorbic acid in plasma is low, the oxidized form of vitamin $C$ in the cells is likely rapidly reduced to ascorbic acid. This seems to be typical for erythrocytes. The reduction is the crucial step since dehydroascorbic acid is not very stable. It has a half-life of about 6 minutes. It is decomposed to 2,3-diketo-1-gulonic acid (Figure 4) and, in this way, it loses its activity of vitamin $C[6,68,73]$. There are apparently redundant pathways mediating the reduction of dehydroascorbic acid to ascorbic acid. They include both direct but slow nonenzymatic reduction by glutathione and enzymatic by a couple of enzymes (e.g., glutaredoxin, glutathione transferase omega 2, or thioredoxin reductase). Of note is that the first two enzymes require glutathione for their activity $[1,73]$. Erythrocytes are very active in mediating this reduction [6,52]. After the reduction to 2,3-diketo-1-gulonic acid, several scenarios may follow. It can be decarboxylated (Figure $4 \mathrm{D}, \mathrm{E})$ and the products can enter the pentose phosphate shunt by a couple of reactions [76]. 2,3-diketo-1-gulonic acid can be spontaneously, but also enzymatically, decomposed to erythrulose and oxalate. This reaction is accelerated by bicarbonate $[1,3]$.

An interesting aspect is the transport of vitamin $C$ to the central nervous system (Figure 2D). The current knowledge suggests that vitamin $C$ is transported to cerebrospinal fluid in the choroid plexus via SVCT2. There are also reports that vitamin $\mathrm{C}$ can pass through the blood-brain barrier in the form of dehydroascorbic acid through the glucose transporter GLUT1 [52,53,73]. Although experimental data reported that penetration of dehydroascorbic acid is apparently much more intense and rapid than that of ascorbic acid [77], physiologically, this transport has likely minor importance. Dehydroascorbic acid is unstable and has very low plasma levels, so its competition with physiological low millimolar plasma levels of glucose for these transporters is rendering that mechanism of uptake of vitamin C in this form via GLUT1 disputable $[53,68]$. Moreover, the absence of SVCT2 in rodents results in very low levels of vitamin C in the brain, clearly emphasizing the importance of this transport for the brain $[69,70]$. The uptake of vitamin $C$ by neuronal cells is very intense and is mediated mainly by SVCT2. GLUT1/3 can also contribute to transporting dehydroascorbic acid to neuronal cells. Neurons possess very high intracellular concentrations of vitamin C, which can reach $10 \mathrm{mM}$, while the concentration in glial cells is similar to other body cells. The cerebrospinal fluid levels are about $200 \mu \mathrm{M}$, which is about four times higher than the average plasma levels. Vitamin $C$ is apparently crucial for the correct functions of the brain and its levels in central nervous system are less affected by vitamin C starving than other tissues [73]. The absence of SVCT2 is incompatible with life $[69,70]$. It was shown that the expression of SVCT2 is increased after experimental vascular brain injury [53]. 


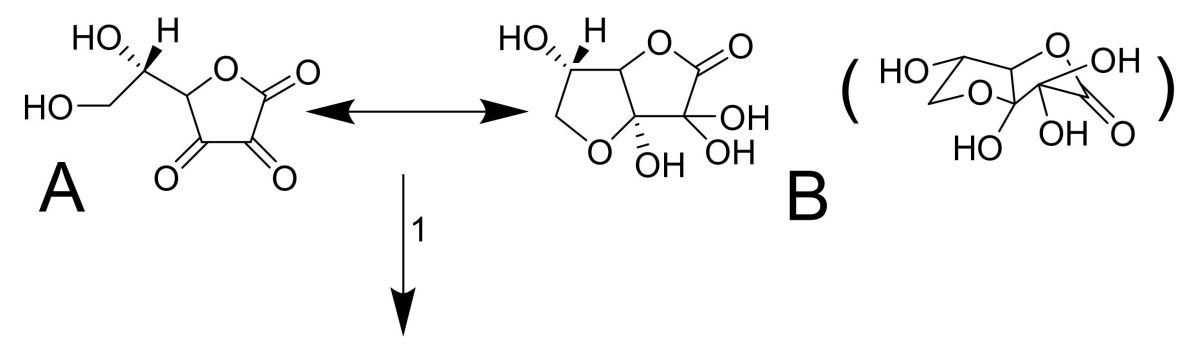<smiles>O=C(O)C(=O)C(=O)C(=O)[C@@H](O)[C@@H](O)CO</smiles><smiles>O=C(O)[C@H](O)[C@@H](O)[C@H](O)CO</smiles>

Figure 4. Dehydroascorbic acid and its decomposition. Dehydroascorbic acid (A) forms reversibly a hemiketal (B, a spatial structure shown in brackets). The structure is not stable and it is irreversibly transformed in 2,3-diketo-1-gulonic acid (C). This compound can be decarboxylated into L-xylonic acid (D) or L-lyxonic acid (E) or in L-erythrulose (F) and oxalate $(\mathbf{G})$. 1: the reaction can be both spontaneous or mediated by an enzyme. 2: No enzyme mediating this reaction was reported. The reaction is likely spontaneous.

According to animal studies, SVCT2 is also important for the transport of vitamin C from the mother to the fetus, but SVCT1 likely participates in this process $[69,70,78]$. The plasma levels of vitamin $C$ in the fetus are higher than in the mother in early pregnancy, which apparently suggests that the fetal uptake of vitamin $C$ is preferred at the expense of the mother [78].

\subsection{Excretion}

Radioactive labelled vitamin $C$ administered to three humans showed that most of the amount is eliminated by the kidney. Only less than $1 \%$ was eliminated by the feces and virtually no vitamin C was breathed out as carbon dioxide. About $20 \%$ of urinary excretion accounted for unmetabolized ascorbic acid, the other $20 \%$ for 2,3-diketo-1-gulonic acid, only $2 \%$ for dehydroascorbic acid, while, on average, $44 \%$ was eliminated in the form of oxalate [79]. Vitamin C is efficiently and saturably reabsorbed from the urinary tract, and SVCT1 plays an important role, as documented by knockout Slc23a1 ${ }^{-/-}$mice with an 18 -fold higher ascorbate excretion $[51,80,81]$. This means that the excess of vitamin $C$ is efficiently eliminated in the urine to maintain the homeostatic vitamin C plasma levels. The player responsible for the saturable reabsorption is, like in the intestine, the SVCT1 transporter, which is expressed on the brush border of the proximal tubules (Figure 2B). Since the $\mathrm{pH}$ of urine is also lower, passive diffusion was suggested but apparently plays 
a minor, if any, role at all [52,53]. The saturable mechanism of reabsorption is responsible for the maintenance of vitamin $C$ plasma concentration together with the saturability of absorption. In daily doses of $30-60 \mathrm{mg}$, almost no vitamin C is excreted in urine within $24 \mathrm{~h}$, while a dose of $100 \mathrm{mg}$ results in $25 \%$ of the dose of vitamin C excreted and doses equalling or above $500 \mathrm{mg}$ are almost entirely excreted [55,57]. The Michaelis constant $K_{\mathrm{m}}$ for renal reabsorption of vitamin $C$ in relation to its plasma levels was suggested to be $33 \mu \mathrm{M}$, which is approximately in line with the maximum plasma levels [57]. The elimination half-life of vitamin $\mathrm{C}$ is generally about $2 \mathrm{~h}$ [52].

\subsection{Genetic Polymorphism}

The influence of genetic variations on vitamin $C$ pharmacokinetics is based on single nucleotide polymorphisms (SNPs) found in SLC23A1 and SLC23A2 genes with a possible association to human diseases (reviewed in References $[2,6]$ ). The strongest evidence to decrease circulating vitamin C levels was found for several common SNPs of SLC23A1 due to reduced renal reabsorption. However, an elevation of vitamin $C$ levels was also seldomly described $[80,82,83]$. These SNPs are more common in the African and AfricanAmerican populations over others, while SNPs of $S l c 23 A 2$ are of a similar frequency in the Caucasian and African populations $[80,82,84]$. SNPs of SLC23A1 were characterized as both synonymous and non-synonymous SNPs (with the greatest diversity found in the African population) producing proteins of lower functionality. In the case of SNPs of $S L C 23 A 2$, all studied polymorphisms were synonymous [80,83]. An effect of individual SNPs on the vitamin $C$ system level has an additive character, which depends on genotype and an allele dosage (additive) effect that was also described. Furthermore, there have also been hundreds of less common or rare SNPs of both genes. Their frequency in populations is unknown, and, therefore, the global significance of SNPs on circulating vitamin C levels as well as their association with diseases needs further investigation $[2,83,85]$.

Some common SLC23A1 polymorphisms were found to be associated with an increased risk of Crohn's disease [86], non-Hodgkin lymphoma [87], preterm delivery [84], and aggressive periodontitis [88]. In addition, no associations were reported between one common variation of $S L C 23 A 1$ and arterial blood pressure or different metabolic parameters [89]. Common variations of SLC23A2 were linked to increased or decreased risk of gastric cancer depending on a discrete genotype [85,90], decreased risk of colorectal adenocarcinoma [91], HPV16-positive head and neck cancer [92], increased risk of bladder cancer [93], non-Hodgkin lymphoma [87], chronic lymphocytic leukemia [94], preterm delivery [84], open-angle glaucoma [95], and acute coronary syndrome in women [96].

\subsection{Physiological Function}

Vitamin $C$ has been undergoing extensive research and we know many processes in which it is involved. Its function appears to be linked dominantly with its electron-donating property [6]. Vitamin C participates in several processes that are related to collagen synthesis, synthesis of hormones (noradrenaline/adrenaline and peptide hormones), synthesis of carnitine, gene transcription, and regulation of translation via different mechanisms (hydroxylation of transcription factors, tRNA and ribosomal proteins, demethylation of DNA, and histones), elimination of tyrosine, protection against reactive oxygen species (ROS), and reduction of iron in the gastrointestinal tract (Figure 5).

\subsection{Vitamin $C$ as an Enzymatic Cofactor}

The enzymatic roles of vitamin $C$ are linked with either dioxygenases (synthesis of collagen and carnitine, involvement in gene transcription, and regulation of translation via different mechanisms and elimination of tyrosine) or monooxygenases (synthesis of hormones). All these vitamin C-dependent oxygenases have a metal, iron, or copper in their active site. The involvement of vitamin $C$ in these enzymatic reactions is well documented. The precise mechanism is, however, not fully elucidated, but appears to be related to reduction or maintenance of these metals in the reduced state. In some cases, vitamin C is 
reduced stoichiometrically within the reaction, suggesting direct involvement. However, in others, the stoichiometry is more complicated, implicating rather that vitamin $C$ can recover the enzymatic function if the central metal atom is oxidized. It should be mentioned that vitamin $C$ seems to be an ideal cofactor for these enzymes. It can be potentially, but not always, replaced by other reductants, which are, however, apparently less active. Individual enzymes and their groups will now be briefly discussed.
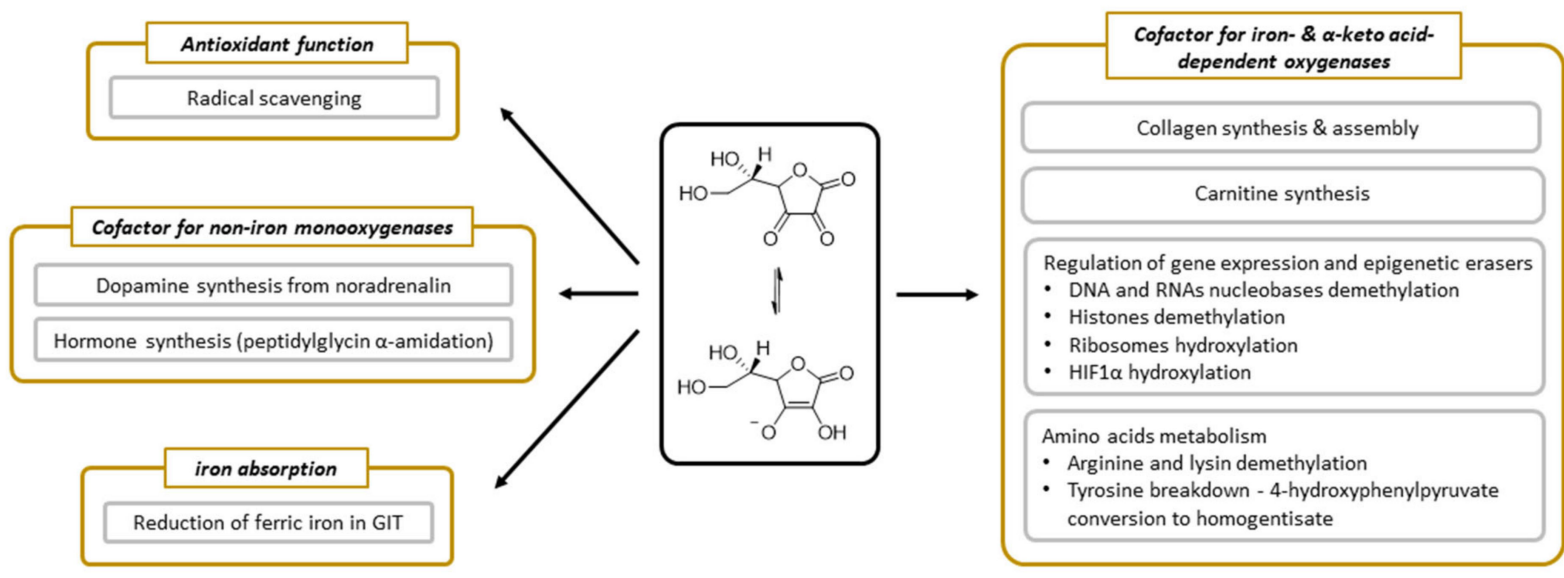

Figure 5. The summary of physiological functions of vitamin C.

\subsection{2-Oxoglutarate-Dependent Dioxygenases}

The largest group of enzymes using vitamin $C$ as one of their cofactors is the irondependent and 2-oxoglutarate-dependent dioxygenases superfamily (2OGO, $\alpha$-ketoglutaratedependent hydroxylases). In humans, it represents about 80 enzymes responsible for the modification of important biological substances and processes (Table 2) [97-99].

The 2OGO were initially identified in the 1970s when studying collagen biosynthesisa formation of hydroxyproline by collagen prolyl-4-hydroxylase enabling collagen crosslinking and, hence, correct formation of connective tissue. It does not need to be emphasized that vitamin $C$ is essential to avoid the symptoms of scurvy related to impaired formation of connective tissue. The role(s) of vitamin C in this reaction cycle is (are) not fully elucidated, but likely the most important role is to maintain the iron atom in the reduced form $[100,101]$. In any case, vitamin C seems to be irreplaceable for the physiological function of these enzymes. It seems to be oxidized during the process, but the oxidation is not stoichiometric in relation to the reaction. This can support the theory of maintaining the central atom in its ferrous form and/or cause its reduction in the enzymatic process, in particular when the enzymatic reaction becomes uncoupled $[4,68,97,101-105]$. A simple, non-selective reduction is rather improbable since glutathione, L-cysteine, or dithiothreitol are inactive. Moreover, the intracellular concentration of vitamin $\mathrm{C}$ should be apparently relatively high for the optimal function of these enzymes since $\mathrm{K}_{\mathrm{m}}$ for vitamin $\mathrm{C}$ ranges from 140 to $300 \mu \mathrm{M}$ [103]. There are also some reports claiming that vitamin $\mathrm{C}$ is not needed, but they were questioned since ferrous ions could, at least, briefly substitute the lack of vitamin C [102]. It is possible that there are differences between individual 2 OGO as carnitine synthesis, which does not require vitamin $C$, according to a complex animal study, and the authors suggested that glutathione can replace it in this case [106].

A relatively new discovery is the finding that vitamin $C$ is the specific cofactor of $2 \mathrm{OGO}$ involved in cellular stress-signalling and epigenetics (reviewed in References [98,101,102,107-109]). It comprises hydroxylases involved in the regulation of the classical cellular sensor hypoxia-inducible factor $1 \alpha$ (HIF1 $\alpha)$, e.g., prolyl-hydroxylase domain-containing proteins (PHDs) and factor inhibiting HIF (FIH) $[110,111]$, and various enzymes involved in epigenetic machinery in humans as epigenetic modification erasers. One of the most known enzyme groups are Jumonji-C (JmjC) domain-containing 
proteins responsible for hydroxylation of specific histone lysines leading to histone demethylation (JmjC demethylases, e.g., JHDMs and KDMs families) [107,112-114]. Ribosomal oxygenases, other members of JmjC domain-containing enzymes with a specific structure containing C-terminal winged-helix (WH)-domains, catalyze histidinehydroxylation in ribosomal proteins rpL27a (MYC-induced nuclear antigen 53, Mina53), and rpL8 (Nucleolar protein 66, NO66) $[115,116]$. Another 2 OGO involved in epigenetic modifications are ten-eleven translocases (TETs) responsible for hydroxylation of 5-methylcytosine to 5-hydroxymethylcytosine primary in DNA [103,114,117-120], and RNA and DNA demethylases from the AlkB family. Currently, we distinguish nine AlkB homologues. ALKBH1-ALKBH8 and ALKBH9 (known previously as FTO (Fat mass and obesity-associated protein)), that are responsible for hydroxylation of methylated nucleoside bases with various substrate specificity [121-125]. Of high importance is the high specificity of FTO and ALKBH5 to demethylate the most frequent internal modification of RNAs, $\mathrm{N}^{6}$-methyladenine $\left(\mathrm{m}^{6} \mathrm{~A}\right)$ [126]. Generally, $2 \mathrm{OGO}$ catalyze specific hydroxylation of substrates, which, in turn, leads to demethylations via other catalytic cycles or downstream pathway involving thymine-DNA-glycosylase, which catalyzed base excision with DNA base excision repair $[101,120]$.

Table 2. Overview of the most important groups of iron-dependent and 2-oxoglutarate-dependent dioxygenases.

\begin{tabular}{cccc}
\hline Physiological Role & Reaction & Enzymes (Subfamily) & References \\
\hline $\begin{array}{c}\text { Collagen stabilization } \\
\text { and maturation }\end{array}$ & Hydroxylation & CP4H, CP3H, PLODs & {$[104,127-129]$} \\
Regulation of HIF-1 $\alpha$ & Hydroxylation & PHDs, FIH & {$[101,110,111,130-133]$} \\
signaling pathway & Histone demethylation & JHDMs, KDMs & {$[102,103,107-109,112-114,134-138]$} \\
Regulation of epigenetic & DNA and RNA demethylation & AlkBHs, FTO & {$[101,103,121-126]$} \\
modifications- & Ribosomal hydroxylation & MINA53, NO66 & {$[115,116,139,140]$} \\
"epigenetic erasers" & Cytosine demethylation & TETs & {$[101-103,114,117-120]$} \\
Carnitine synthesis & Hydroxylation & TMLHE, BBOX & {$[4,141-143]$} \\
\hline
\end{tabular}

$\mathrm{CP} 4 \mathrm{H}, \mathrm{CP} 3 \mathrm{H}-$ collagen prolyl-4-hydroxylase and -3-hydroxylase. PLODs, pro-collagen lysine 2-oxoglutarate 5-dioxygenases. HIF, hypoxiainducible factor. PHDs, prolyl hydroxylase domain-containing proteins. FIH, factor inhibiting HIF. JHDMs, Jumonji-C domain histone demethylase. KDMs, lysine demethylases. AlkBHs, alkylated DNA repair protein AlkB homologs. FTO, fat-mass and obesity-associated protein. MINA53, Myc-induced nuclear antigen 53. NO66, nucleolar protein 66. TET, ten-eleven translocases. TMLHE, trimethyllysine hydroxylase epsilon. BBOX, gamma-butyrobetaine dioxygenase.

The last known vitamin C-dependent dioxygenase is 4-hydroxyphenylpyruvate dioxygenase. It is classified with $2 \mathrm{OGO}$ into $\alpha$-keto acid-dependent oxygenases. It has a ferrous ion again in the active site and needs oxygen. It catalyzes an uncommon reaction in humans, which involves decarboxylation, substituent migration, and aromatic oxygenation in a single catalytic cycle. The 4-hydroxyphenylpyruvate is converted to homogentisate (2,5-dihydroxyphenylacetate, Figure 6) as a part of the tyrosine elimination pathway. Furthermore, here, the superiority of vitamin $C$ over other reducing agents was shown $[4,144]$.
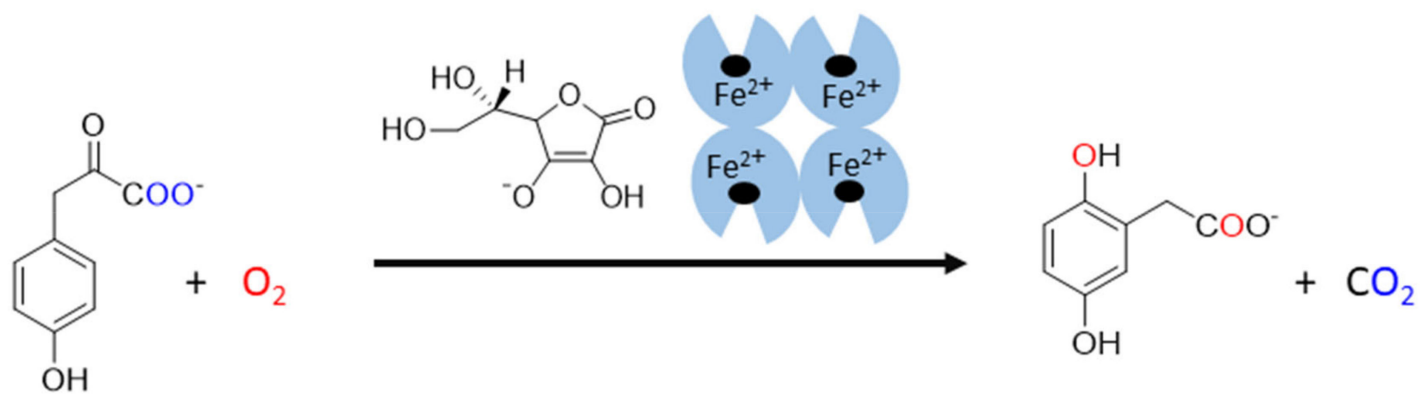

Figure 6. The reaction catalyzed by human 4-hydroxyphenylpyruvate dioxygenase. 4-hydroxyphenylpyruvate is oxidized by molecular oxygen by the enzyme in the presence of ascorbate. The products of this reaction are homogentisate (2,5dihydroxyphenylacetate) and carbon dioxide. The origin of oxygen is highlighted in a blue and red color. 


\subsection{Vitamin C-Dependent Monooxygenases}

There are two monooxygenases dependent on vitamin C: dopamine- $\beta$-hydroxylase and peptidyl-glycine $\alpha$-amidating monooxygenase (PAM). Both are, hence, associated with the synthesis of hormones. There is a significant homology both in the amino acid sequence and the final structure between them [72]. Dopamine- $\beta$-hydroxylase is located in catecholamine storage vesicles of nervous tissue including in chromaffin cells of the adrenal medulla. It is a dimer or tetramer containing identical subunits with each possessing two catalytical copper ions. Ascorbic acid seems to be involved in the reduction of copper. The process appears to be very similar to PAM $[4,72,145,146]$. PAM is a bifunctional enzyme catalyzing two-step carboxyterminal amidation of peptides. It is expressed in at least seven protein forms, which are the results of different RNA splicing ranging from trans-Golgi membrane-bound to free forms. It is the only known human enzyme able to catalyze $\alpha$-amidation of peptides [72,147-149]. The reaction is crucial for the production of a number of hormones/neurotransmitters (e.g., calcitonin, oxytocin, vasopressin, GLP-1, substance $\mathrm{P}$, neuropeptide $\mathrm{Y}$ ), and the enzyme is highly expressed in many neurons and endocrine tissues $[4,72,150-153]$. The enzyme can also amidate non-proteins such as fatty acid glycines [72]. It is composed of two active enzymatic sites with one catalyzing hydroxylation of the $\alpha$-carbon of glycine (called peptidyl-glycine $\alpha$-hydroxylating monooxygenase), and the other dealkylation of the hydroxyglycine intermediate by the release of glyoxylate ( $\alpha$-hydroxyglycine $\alpha$-amidating lyase or peptidylamidoglycolate lyase, Figure 7). The former active site is composed of two copper ions and the corresponding reaction is ascorbate-dependent. Ascorbate likely enables conversion between a cupric and cuprous state and is reduced stoichiometrically to an ascorbyl radical. Other reductants can replace ascorbic acid but are less potent [4,72,147-149].

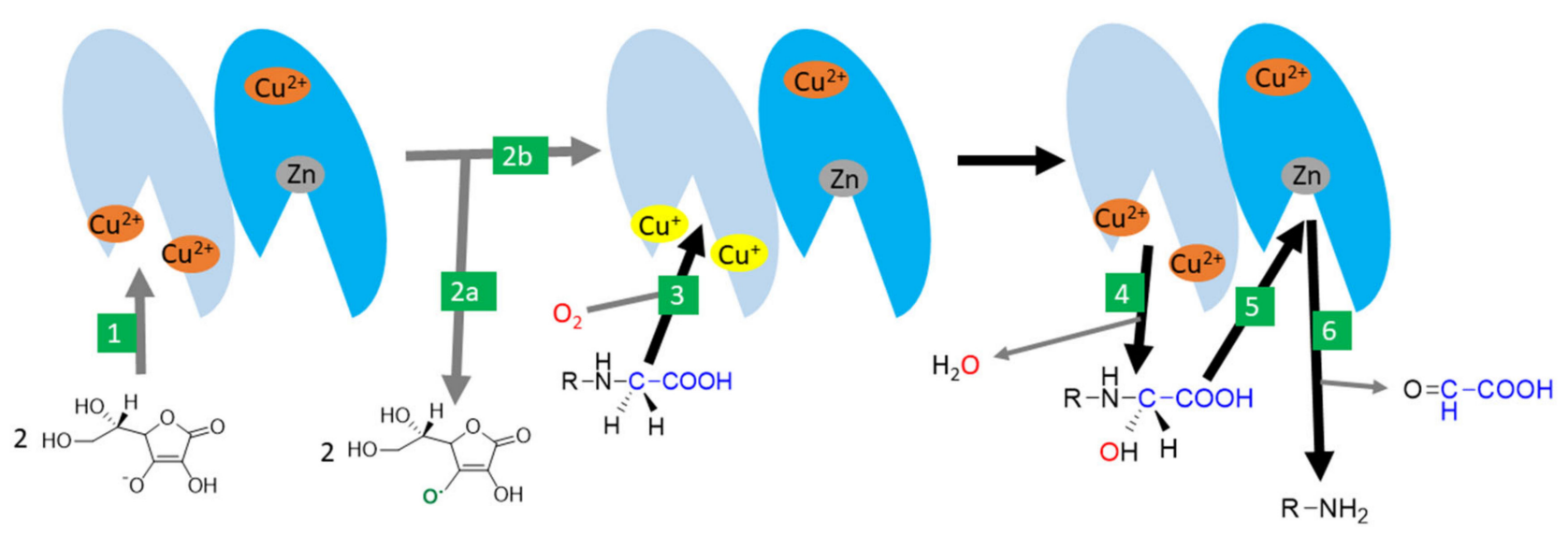

Figure 7. Amidation catalysed by peptidyl-glycine $\alpha$-amidating monooxygenase (PAM) -the likely mechanism. 1: Ascorbic acid reduces cupric ions in the active site of the peptidyl-glycine $\alpha$-hydroxylating monooxygenase domain (shown in light blue). 2: two molecules of ascorbic acid are oxidized to ascorbyl radical (2a) and the active enzyme with reduced cuprous ions in the active site is formed (2b). 3: This active site binds the substrate and needs oxygen for the reaction as well. 4: One oxygen is incorporated in the water while the second is incorporated in the substrate. 5: The reaction continues, with the binding of the hydroxylated site to the active center with a zinc atom of the $\alpha$-hydroxyglycine $\alpha$-amidating lyase domain of the enzyme (shown in dark blue). 6: This results in the production of the $\alpha$-amidated enzyme and the release of glyoxylate.

\subsection{Vitamin $C$ as an Anti/Prooxidant}

The involvement of vitamin $\mathrm{C}$ as an endogenous antioxidant, e.g., scavenger of ROS, is still a matter of debate. Its role has been clearly and repeatedly demonstrated in vitro, but in vivo, the situation is less clear [5,6,154-156]. A good example is a fetus without an SVCT2 transporter. These fetuses have no vitamin $C$ in the cortex and lungs together with lower levels of vitamin $C$ in the placenta. The markers of lipid peroxidation are clearly elevated in the cortex and placenta but not in the lungs [69]. The effect of ascorbic acid 
on the recovery of $\alpha$-tocopherol (Figure 8) and recovery/sparing of tetrahydrobiopterine (Figure 9) is mostly discussed in the literature to have biological relevance [157-159] as these activities are associated with protection against endothelial dysfunction.
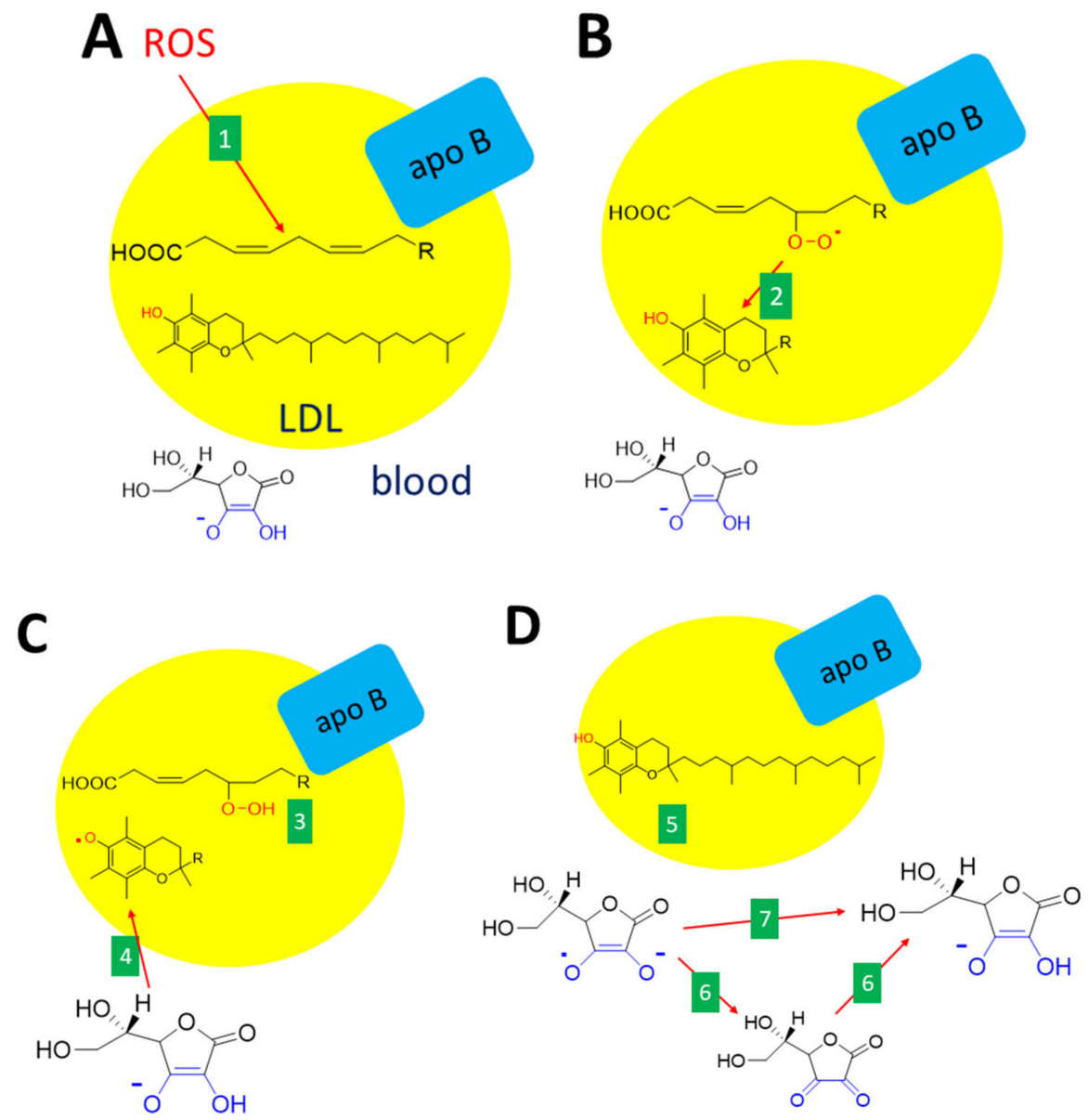

Figure 8. Interconnection between antioxidant effects of vitamin C and E. (A): Unsaturated fatty acid within the LDL (low-density lipoproteins) particle is oxidized (e.g., by other ROS, 1). (B): The lipid peroxy radical formed is neutralized by vitamin $\mathrm{E}$ ( $\alpha$-tocopherol, 2$)$. $(\mathbf{C})$ : The reaction results in a lipid hydroperoxide (3) and the formation of the $\alpha$-tocopheryl radical, which immediately reacts with vitamin C (ascorbate, 4). (D): This leads to the recovery of $\alpha$-tocopherol (5) and the formation of an ascorbate free radical. Ascorbate can be recovered either via dehydroascorbic acid (6) or directly (7). The are several ways how these reactions can be accomplished either non-enzymatically or enzymatically.

Oxidative modification of protein moiety of low-density lipoproteins (LDL) can happen in vivo due to oxidative stress via the ROS formed, e.g., by leukocytes. The first line antioxidant in this case is $\alpha$-tocopherol, which is the most abundant antioxidant in LDL. However, the formed $\alpha$-tocopherol radical can act as a prooxidant if not scavenged. Here, the ascorbic acid seems to play a crucial role since it recovers $\alpha$-tocopherol [157]. The formed ascorbate (ascorbyl) free radical, also known as monodehydroascorbate or semidehydroascorbate, is quite stable and can be detected in biological fluids in a concentration of $10 \mathrm{nM}[73,154]$. This radical is not very reactive and its preferred reaction is the formation of dehydroascorbic acid from two molecules of this radical. The radical can also be directly transformed to ascorbic acid by NADH-dependent or NADPH-dependent enzymes, such as thioredoxin reductase and cytochrome $b_{5}$ reductase. Again here, redundant pathways apparently exist. In addition, intracellular cytochrome $b_{561}$ and/or some not fully defined plasma membrane redox system apparently participate in this process $[1,68,73,76]$. 
Recovery and/or protection of tetrahydrobiopterin $\left(\mathrm{BH}_{4}\right)$ by vitamin $\mathrm{C}$ is another issue (Figure 9). There are verifications that higher intake/plasma levels of vitamin C are associated with higher levels of tetrahydrobiopterin [158]. The mechanism of how vitamin $\mathrm{C}$ maintains $\mathrm{BH}_{4}$ levels is not fully clear. Vitamin $\mathrm{C}$ recovers $\mathrm{BH}_{4}$ from the trihydrobiopterin radical. Although this reaction is relatively specific and thiols like glutathione are not active, the same reduction to $\mathrm{BH}_{4}$ can also be performed by the enzyme endothelial NOsynthase (eNOS) itself. Hence, the protection of $\mathrm{BH}_{4}$ due to scavenging of other radicals that can oxidize $\mathrm{BH}_{4}$, is a more likely mechanism. For example, the affinity of $\mathrm{BH}_{4}$ and ascorbate for superoxide are about the same magnitude. Without $\mathrm{BH}_{4}$, which stabilizes all human NOS, eNOS will become uncoupled and produce superoxide instead of NO. ROS can oxidize $\mathrm{BH}_{4}$ and, hence, decrease its availability for eNOS. One of the oxidation products is also dihydrobiopterin $\left(\mathrm{BH}_{2}\right)$, which binds to eNOS, but causes the mentioned uncoupling [68,157,158,160-162]. However, ascorbate cannot recover $\mathrm{BH}_{4}$ from $\mathrm{BH}_{2}$ [162].

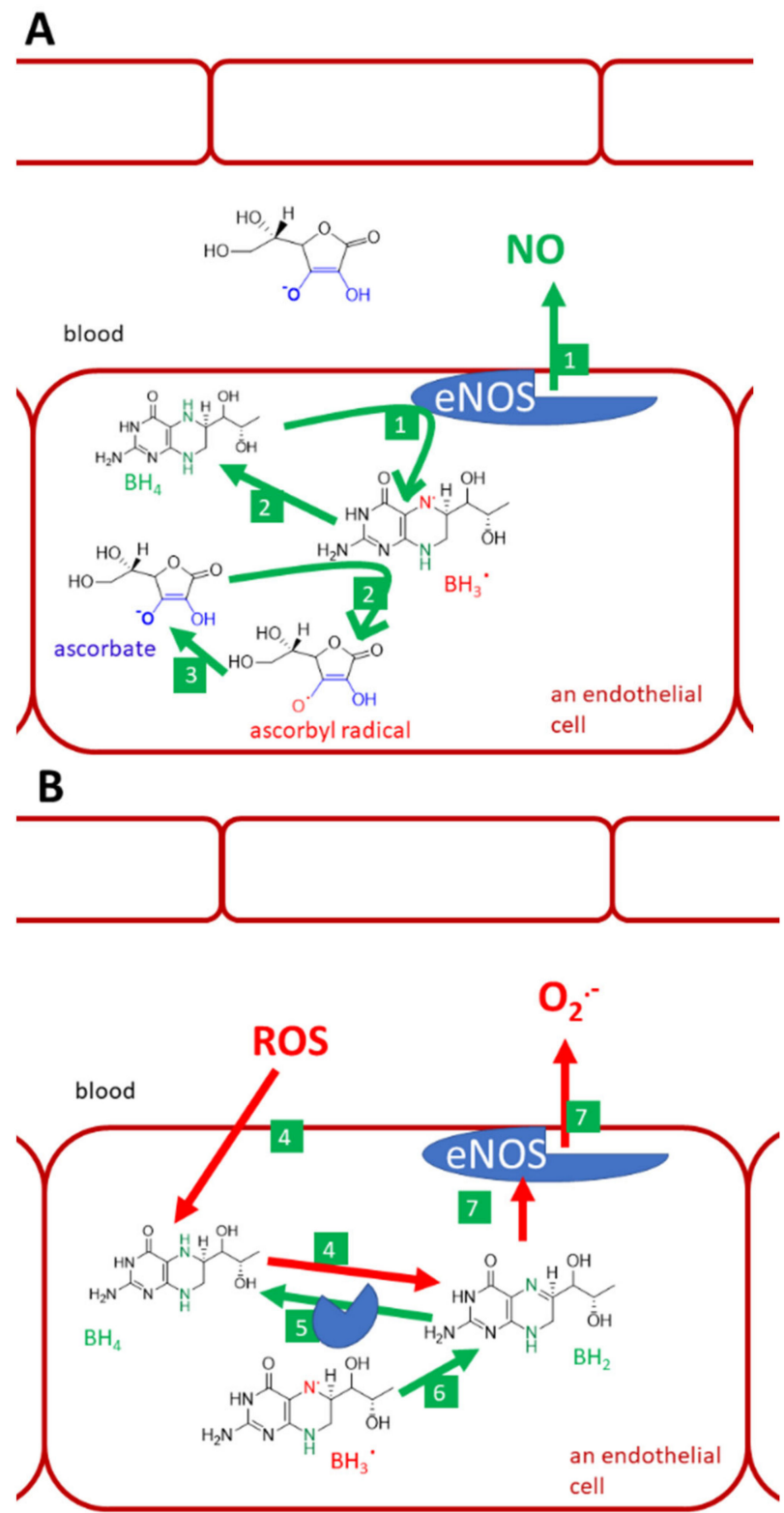

Figure 9. Cont. 


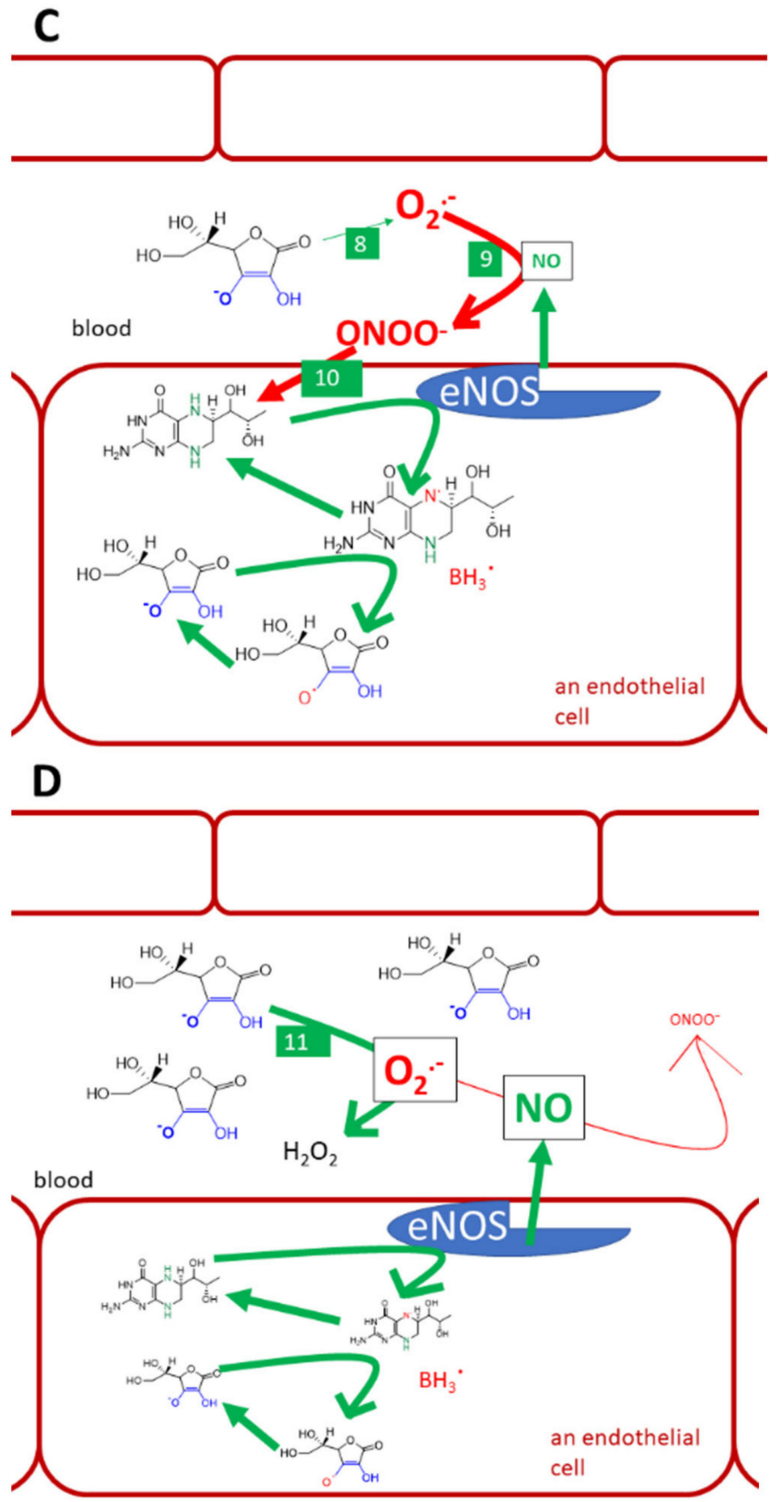

Figure 9. Vitamin C, tetrahydrobiopterin, and endothelial NO-synthase (eNOS). (A): normal conditions, (B): lack of vitamin $C$ and oxidative stress, (C): physiological levels of vitamin $C$ and oxidative stress in the vascular system, (D): i.v. administration of high vitamin C doses. Under normal conditions, tetrahydrobiopterin $\left(\mathrm{BH}_{4}\right)$ is used by the eNOS for the synthesis of $\mathrm{NO}(\mathbf{1})$. Trihydrobiopterin radical $\left(\mathrm{BH}_{3} \cdot\right)$ can be generated by eNOS. It can be recovered to $\mathrm{BH}_{4}$ by both eNOS itself or ascorbate (2). Ascorbate is recovered from the ascorbyl radical (3) by several pathways discussed in this article. Under the lack of vitamin $\mathrm{C}$ and under oxidative stress, $\mathrm{BH}_{4}$ is oxidized by reactive oxygen species (ROS). This decreases the availability of this cofactor and may lead to the formation of dihydrobiopterin $\left(\mathrm{BH}_{2}, 4\right) . \mathrm{BH}_{2}$ can be reduced back to $\mathrm{BH}_{4}$ by dihydrofolate reductase (5). Similarly, if $\mathrm{BH}_{3} \cdot$ cannot be recovered to $\mathrm{BH}_{4}$, it can be oxidized to dihydrobiopterin $\left(\mathrm{BH}_{2}, 6\right) . \mathrm{BH}_{2}$ binds to eNOS, but causes uncoupling. Such an enzyme can no longer produce NO, but produces superoxide instead (7). Oxidative stress is demonstrated since elevated levels of superoxide in circulation cannot be normalized by physiological concentrations of vitamin $C$, which has a lower affinity to superoxide (8) than superoxide has to NO. As a result, the protective NO is reacting with superoxide into highly reactive peroxynitrite (9). Peroxynitrite can also oxidize $\mathrm{BH}_{4}(\mathbf{1 0})$ and cause eNOS uncoupling, as was shown in part B (No. 4). However, when vitamin C is given in high doses intravenously, it reaches $\mathrm{mM}$ levels and is considered to compete with NO for the superoxide (11). The superoxide is neutralized by such a high concentration of vitamin $\mathrm{C}$ and $\mathrm{NO}$ can exert its endothelial protective function. 
The role of vitamin $C$ in the prevention of endothelial dysfunction is further supported by other findings: (1) it prevents leucocytes adhesion to endothelial cells caused by both oxidized LDL and cigarette smoke [157], (2) it decreases ROS levels in endothelial cells in vitro [163], (3) it recovers flow-dependent vasodilation impaired by smoking and normalizes TBARS (thiobarbituric acid reactive substances, a non-selective marker of lipid peroxidation) in smokers [63], and, (4) similarly, flow-dependent vasodilation was also improved in patients with coronary artery disease after administration of vitamin C [164]. In addition, the phenomenon of nitrate tolerance, which can also be associated with ROS, can be abolished by vitamin C [165].

However, there are also reports opposing the antioxidant theory. Multiple studies showed no effect of vitamin $C$ on markers of lipid peroxidation in healthy humans or animals $[63,66,166]$. Furthermore, very high-mortality of mice injected by Klebsiella pneumoniae was markedly abolished by vitamin $C$, but the effect was not associated with antioxidant activity since vitamin $C$ did not impact neither lipid nor protein oxidation [155]. Notwithstanding the positive effect on flow-mediated dilation, markers of lipid and protein oxidation were not positively modified after the administration of vitamin $\mathrm{C}$ in patients with coronary artery disease [164]. The scavenging effects of ascorbic acid on a superoxide are also debatable. In simple experiments, vitamin $C$ is a very active superoxide scavenger. However, in competition with $\mathrm{NO}$, a concentration of vitamin $\mathrm{C}$ about $10 \mathrm{mM}$ is needed to block the interaction of $\mathrm{NO}$ with the superoxide by effective scavenging of the latter [167]. The reaction of the superoxide with $\mathrm{NO}$ is preferred and leads to the production of reactive peroxynitrite [167]. A high concentration of vitamin C can be, however, present intracellularly, as mentioned, in neurons or in plasma after i.v. treatment with high doses of vitamin C $[157,158]$. On the other hand, glutathione has about 100x lower affinity to superoxide than vitamin C. In general, it appears that ascorbate is the first line hydrophilic antioxidant. Contrarily, glutathione is about twice more active in scavenging peroxynitrite than ascorbate [68].

Higher doses of vitamin $C$ can behave as a prooxidant $[156,168,169]$ and this property is potentially useful for cancer treatment and will be discussed in the chapter entitled Cancer.

\subsection{Vitamin C and Iron Absorption}

The last known function of vitamin $C$ is associated again with its potential to reduce ferric ions into ferrous ones. In this way, vitamin $C$ increases iron absorption even with a low amount of vitamin $C$ corresponding to its content in a normal diet $[5,154]$.

\subsection{Vitamin C Deficiency}

Vitamin C deficiency is known as scurvy. Typical symptoms of scurvy are muscle weakness, swollen and bleeding gums, loss of teeth, petechial hemorrhaging, spontaneous ecchymoses, anemia, impaired would healing, hyperkeratosis, weakness, myalgia, arthralgia, and weight loss (there can also be a paradoxical weight increase due to swelling) while the early manifestations encompass lethargy, lassitude, and irritability. Dyspnea can be observed as well. The scurvy is potentially fatal and sudden death occurred as a consequence of a cerebral/myocardial hemorrhage or pneumonia. Biochemically, vitamin C plasma levels below $11 \mu \mathrm{M}$ are considered to coincide with clinical symptoms of scurvy. Similarly, symptoms are not seen unless the total vitamin $C$ content in the body falls below $300-400 \mathrm{mg}[2,3,6,157,170]$.

The direct links of vitamin $C$ with symptoms of scurvy are not easily ascertained due to the complexity of vitamin $C$ functions and its partial replaceability with different reductants [4]. The first mentioned symptoms of vitamin $C$ deficiency such as lassitude and tiredness, occurring at plasma levels approximately below $20 \mu \mathrm{M}$, can be due to decreased synthesis of carnitine since a deficiency in carnitine leads to decreased oxidation of fatty acids in muscles and other tissues. It can also be related to decreased synthesis of hormones, e.g., norepinephrine and epinephrine $[4-6,154]$. Peripheral neuropathy after vitamin C encompassing numbness of calves and pain might be related to the epigenetic effect of 
vitamin C. It is known that vitamin $C$ is needed for myelin formation by Schwann cells and it is thought that these symptoms of peripheral neuropathy can be due to the lack of demethylating effects of vitamin C, which can affect the epigenomic way of activation, proliferation, and differentiation of Schwann cells [102].

In the absence of vitamin C, prolyl-4-hydroxylase and lysyl hydroxylases cannot catalyze the hydroxylation. Collagen synthesis is defective and this leads to symptoms of scurvy. Hydroxylation of prolyl residues is needed for the formation of a stable triplehelical procollagen, while lysyl hydroxylation seems to participate in collagen crosslinking as well as in enabling other posttranslational modifications, such as glycosylation and phosphorylation $[104,128,129]$. Some mild decreases in the hydroxylation of amino acids in collagen were observed in models of vitamin $C$ deficiency. The effect of the absence of vitamin $\mathrm{C}$ might be more complex and, in addition to low hydroxylation, there are also reports of decreased synthesis of collagen and other extracellular matrix proteins. Additionally, other connective tissue proteins are physiologically hydroxylated in proline residues, e.g., elastins $[4,71,171]$. Fetuses without vitamin $C$ in the brain have severe hemorrhages and there is apparently less collagen type IV in the basement membrane of brain vessels $[69,70]$. Hence, the overt symptoms of vitamin $C$ deficiency such as bleeding or poor healing are associated with abnormalities in connective tissue synthesis.

Although the time when scurvy was a relatively frequent phenomenon has gone, in the relatively close past and even in the current time, the vitamin C deficiency is not fully overcome [3]. It can be observed in refugees and, quite surprisingly, a national survey in the United States in the years 2003-2004 reported that 7\% of persons had a vitamin C plasma level below $11.4 \mu \mathrm{M}$ [61]. The situation seems to be gradually improving since, apparently, vitamin C supplements and socioeconomic status are important factors [61]. As already discussed, smokers are at much higher risk [2]. Additionally, there are several pathologies and other situations in which the level of vitamin C drops in plasma [159]. These are likely associated with an enhanced need for vitamin C. Not surprisingly, surgery, trauma, sepsis, and burns are causing a decrease in blood vitamin $C$ and, in very serious injuries, the drop can be very pronounced $[172,173]$. Furthermore, acute myocardial infarction is associated with rapid loss of vitamin $C$ both in plasma and tissues [60,174]. Lower levels are also observed in cancer patients. Additionally, 30\% of solid cancer patients had vitamin C levels below $11 \mu \mathrm{M}$, while $19 \%$ of patients with similar values were observed in a group of hematological malignancies $[59,175]$. Moreover, the other $42 \%$ of patients with solid cancer had levels in the range of $11-23 \mu \mathrm{M}$ and the average level of plasma vitamin $\mathrm{C}$ in haematologic cancer patients was $20.5 \mu \mathrm{M}[59,175]$. The low intake of vitamin $C$ is markedly contributing to those patients [175]. In patients suffering from atopic dermatitis, the plasma vitamin C levels are normal, but their dermis contains approximately four times less vitamin C [176].

\subsection{Possible Use of Vitamin C in Therapeutics Cancer}

As mentioned, patients with cancer often have lower plasma levels of vitamin $C$ than healthy adults. Moreover, vitamin $\mathrm{C}$ deficiency is associated with higher C-reactive protein levels and with higher mortality $[2,175,177]$. Some clinical trials with high doses of vitamin $C$ failed to show a benefit in cancer patients because vitamin $C$ was administered orally in these studies $[154,178,179]$. This seems to be largely based on the limits of oral vitamin C to elevate plasma levels. For vitamin $C$ to have a therapeutic impact on cancer, it should be given intravenously to achieve plasma levels in $\mathrm{mM}$. Low concentrations of vitamin C achieved by oral administration are antioxidant while higher procurable by intravenous administration of grams doses are prooxidant and also increase the effect of some cytostatics (e.g., arsenic trioxide, carboplatin, and paclitaxel) and radiotherapy [103]. It was shown that vitamin $C$ given intravenously increases the production of hydrogen peroxide dosedependently in extracellular fluid but not in blood. High doses of vitamin $\mathrm{C}$ leading to its maximal average concentration of $10 \mathrm{mM}$ in plasma resulted up a concentration of 
about $20 \mu \mathrm{M}$ of hydrogen peroxide. This was considered a consequence of increased levels of ascorbyl radical, which achieved $250 \mathrm{nM}$ in extracellular fluid $[67,180]$. The levels of ascorbyl radical and hydrogen peroxide in the tumour or s.c. tissues in mice were even higher [181]. The elevated levels of hydrogen peroxide seem to be one of the possible reasons for the anticancer effect of high doses of vitamin $C$. In addition to this prooxidant effect, HIF $1 \alpha$ and epigenetic pathways can contribute to the possible anticancer effect of vitamin C [177]. The viability of healthy cells is not affected by vitamin $C$ even at $20 \mathrm{mM}$ concentration, i.e., at common concentrations achieved by administration of high doses of vitamin $\mathrm{C}$. Tumor cells are much more, although variably, sensitive to vitamin C, with $\mathrm{EC}_{50}$ of vitamin $\mathrm{C}$ below $20 \mathrm{mM}$ in all tested cases of human and mouse cancer cells lines $[180,181]$. A significant number of clinical trials have indicated that vitamin C administered intravenously in high-doses (in most trials, 50-100 $\mathrm{g}$ twice or thrice weekly) as a treatment for various cancers including glioblastoma, ovarian, prostate, lung, or rectum cancer is well tolerated with minimal toxicity, improves the quality of life for patients, and has a synergistic therapeutic effect when combined with radiation and/or standard chemotherapy and reduced their side effects. However, most of these studies were not designed as large-scale randomized clinical trials and clear verifications of the clinical efficacy of vitamin C are currently rather limited [177,182-184]. On the other hand, the therapy with a high dose of vitamin $C$ can also have some relevant risks for the patients with some type of cancer treatment. Vitamin C in high doses $(40 \mathrm{mg} / \mathrm{kg} /$ day orally) can significantly reduce the activity of bortezomib treatment in vivo in the human multiple myeloma xenograph model [185].

There is some evidence that vitamin $C$ administered orally may be effective to prevent the development of certain types of malignities (e.g., lung cancer, colorectal adenoma, endometrial cancer) [186-188]. On the other hand, there is a reasonable discussion of how much these studies were confounded by other factors such as healthier diet, etc. [5].

Summing up, through low toxicity and low financial cost, high-dose intravenous vitamin $C$ may be possibly a beneficial adjuvant for conventional cancer therapy in certain types of tumors. Oral intake of vitamin $C$ in high doses could be effective in cancer prevention. High-quality placebo-controlled clinical trials are, however, crucially needed to verify and specify the effect of vitamin $C$ both in the treatment and prevention of cancer.

\subsection{Cardiovascular Diseases}

Based on the reported positive antioxidant effect of vitamin C in relation to endothelial dysfunction, many studies investigated the possible protective effect of vitamin $C$ on cardiovascular diseases. Higher levels of plasma vitamin $C$ are correlated with a lower risk of coronary artery disease and mortality in terms of cardiovascular diseases. However, this relationship seems to be valid only for inadequate plasma levels. In adequate vitamin C plasma levels, supplementation with vitamin $C$ has a little effect $[2,5,189]$. Recent umbrella review brings only limited evidence for the effect of vitamin $C$ supplementation on biomarkers of cardiovascular diseases or its risk factors, such as arterial stiffness, blood pressure, endothelial function, glycemic control, and lipid profile. There is only weak evidence that supplemental vitamin $\mathrm{C}$ may improve these biomarkers in selected population subgroups (older and/or obese people, patients with lower vitamin C status at baseline, and patients with a higher risk of cardiovascular disease) [190]. Some recent systematic reviews and meta-analyses suggested that vitamin $C$ significantly decreased the incidence of atrial fibrillation, ventilation time, length-of-stay in the intensive care unit, and hospital length-of-stay, but it had no significant effect on in-hospital mortality or incidence of stroke, acute kidney injury, or ventricular arrhythmia in cardiac surgery patients. The data on the effect of vitamin $C$ on clinical outcomes in patients undergoing cardiac surgery is still insufficient to draw firm conclusions [191-194]. 


\subsection{Infections}

The role of vitamin $C$ in the protection of infections was nicely summarized in a recent review [157]. It can be shortly summarized that vitamin $C$ is important for the differentiation and function of immune cells and epithelial barrier cells. Patients with infections have lower levels of vitamin $C$ and animal models have largely shown a protective effect of vitamin C on different infections or intoxications with bacterial toxins $[155,195]$. The human studies are, however, much less clear. The Cochrane library has not documented the preventive effect of vitamin $C$ administration on the incidence of the common cold and found only a very mild effect on the duration of the common cold. The effect of vitamin C in the prevention and treatment of pneumonia is uncertain as well $[196,197]$. Notwithstanding that the effect is absent in the general population, vitamin $C$ can be effective under specific conditions, such as low levels of vitamin C, e.g., in people under physical stress $[6,191,195,198]$. The recent clinical trial did not find the effect of intravenous vitamin $C$ infusion on organ failure and biological markers of inflammation and vascular injury in patients with sepsis and acute respiratory distress syndrome, but vitamin C compared with the placebo was associated with a significant reduction in 28-day all-cause mortality [199]. There are also some other clinical limited reports showing that vitamin C can improve the consequences of sepsis [200].

Due to the possible positive effects on respiratory diseases, acute respiratory distress syndrome and sepsis, low cost and excellent safety profile, administrations of vitamin $C$ to patients with hypovitaminosis $C$, and severe respiratory infections, e.g., COVID-19, could appear warranted. However, there is currently only one small clinical trial reporting the possible effect on mortality in more severely ill COVID-19 patients who received vitamin C intervention. Currently, there are many randomized controlled trials registered globally assessing the effect of intravenous vitamin C in patients with COVID-19 in which outcomes are awaited with interest [201,202].

Vitamin $\mathrm{C}$ was also claimed to decrease the $\mathrm{pH}$ of urine and, hence, to be useful in the prevention of recurrent urinary infections. However, it was shown that even high doses of vitamin C do not decrease the $\mathrm{pH}$ of urine [203].

\subsection{Other}

Vitamin $C$ is frequently added to oral preparations containing iron in order to increase iron absorption $[5,154]$. In a recent meta-analysis, patients who received intravenous vitamin $C$ perioperatively had significant pain reduction and decreased morphine requirements [204].

\subsection{Toxicity}

A single oral dose of vitamin C of 5-10 g produces transient osmotic diarrhea and/or abdominal bloating with pain but, otherwise, even such a high dose is considered to be safe. However, this is not recommended. Intake with food can decrease these adverse reactions $[3,5,156,172]$. High, in particular i.v., the dose is described to produce polyuria by the same mechanism [203,205]. Interestingly, even very high doses of i.v. vitamin C (ranging from 1 to $200 \mathrm{~g}$ and given repeatedly) are apparently well tolerated in most patients [206]. Vitamin C is metabolized partly into oxalate (Figure 4) in the human organism. Vitamin C increases oxalate levels in urine dose-dependently and there are concerns about possible urinary stone formation. The question is somehow controversial since early methods overestimated oxalate levels in urine due to experimental artifacts $[5,55,203,205,207,208]$. Interestingly, parenteral preparations of vitamin $\mathrm{C}$ might also contain oxalate, likely because oxalate is easily formed in vitro from vitamin $\mathrm{C}$ at a higher $\mathrm{pH}$ [205]. In any case, although urinary oxalate is the crucial player in calcium stone formation, the risk of urinary stone formation seems to be very low after intake, even of high vitamin $C$ doses. The major reason is that, in general, long-term high concentrations of oxalate in urine are needed for developing the stones. It cannot be, however, ignored since some persons might be at higher risk. For example, higher basal urinary levels of oxalate are found in "urinary 
stone formers" and, similarly, vitamin C administration is inducing higher urinary levels of oxalate in these patients than in non-formers [203,206-208]. A prospective cohort study suggested that intake of oral doses of vitamin $\mathrm{C}$ higher than $1 \mathrm{~g}$ increases the risk of stone formation significantly by $41 \%$ [209]. For this reason, higher doses of vitamin C than $1 \mathrm{~g}$ daily should not be routinely recommended [5]. Of note, high doses of vitamin $C$ were also described to increase urate excretion transiently $[5,55]$.

Intravenous vitamin $C$ or very high oral vitamin $C$ doses can precipitate hemolysis in glucose-6-phosphate deficiency patients [5]. Oral ascorbic acid can worsen hemolysis in patients suffering from paroxysmal nocturnal hemoglobinuria [210]. In vitro, the effect of vitamin C on the lysis of red blood cells from these patients is concentration-dependent with worsening in low concentrations while inhibition occurred in high concentrations $[105,210]$.

It should also be mentioned that a high intake of vitamin $C$ in mothers can result in rebound scurvy in new-borns [3].

\subsection{Determination of Vitamin C in Biological Material}

In general, determining the presence of L-ascorbic acid in a biological sample is a difficult task due to the possible interference with several variables. The stability of L-ascorbic acid is the major problem. Since vitamin $C$ is a known antioxidant, its oxidation in the human body into dehydroascorbic acid has been proposed as an in vitro marker of oxidative stress. However, the oxidation occurs rather quickly and, hence, also artificially after collecting the sample. Although dehydroascorbic acid is far more stable than L-ascorbic acid, it may still undergo irreversible hydrolysis in 2,3-diketogluconate (Figure 4). Dehydroascorbic acid concentration in healthy adults is normally below $2 \%$ of that of L-ascorbic acid [211]. Moreover, the simultaneous determination of both is difficult because of the different physicochemical properties of these analytes. Therefore, the simultaneous determination is achieved via a double analysis of one sample with a redox reaction conversion (oxidation of the former/reduction of the latter) and subsequent subtraction. However, this procedure often lacks specificity and is prone to the interference of other reducing agents. This problem can be solved by combining different detection techniques. It should be pointed out, though, that vitamin $C$ in urine can interfere with urine stripe tests. For example, vitamin $C$ can cause false positive or false negative results during the detection of glucose, leukocytes, nitrite, and bilirubin [212].

The stability of L-ascorbic acid in aqueous solutions can be affected by a number of factors including light, temperature, $\mathrm{pH}$, and presence of oxygen and metal ions, which must be considered during its determination. In this regard, the concentration of L-ascorbic acid can decrease during exposure to UV light (decrease to 80\%), natural light in a transparent container (decrease to $84 \%$ ), and in a brown flask (decrease to $96 \%$ ). Most studies concerning biological material used samples cooled to $4{ }^{\circ} \mathrm{C}$ immediately after collection because the concentration of L-ascrobic acid decreases rapidly at higher temperatures. These samples can be stable only for $1 \mathrm{~h}$ at room temperature. Most of the published protocols for the extraction of L-ascrorbic acid from biological material use acidic $\mathrm{pH} 2.1$ to improve the stability of L-ascorbic acid. On the other hand, both L-ascorbic and dehydroascorbic acid display better stability at higher concentrations. Their stability decreases significantly when their concentration is lower than $0.1 \mathrm{mg} / \mathrm{L}$. L-ascorbic acid can also be degraded in the presence of oxidizing enzymes and metal ions, especially $\mathrm{Cu}^{2+}$ and $\mathrm{Fe}^{2+}[213,214]$. The usage of anticoagulants for blood collection also plays an important role. Heparin and ethylenediaminetetraacetic acid (EDTA) on ice are the most suitable since L-ascorbic acid is unstable with gel or fluoride anticoagulants [215]. Thus, a number of preventive steps should be followed to avoid the degradation of the analytes when processing biological material for determining L-ascorbic and dehydroascorbic acid. In general, the rapid transport of the sample to the laboratory in a dark container at low temperature should be procured. Some stabilizers, such as meta-phosphoric acid trichloroacetic acid, homocysteine, trifluoroacetic acid, oxalic acid, and EDTA (for chelating undesirable metal ions), are often added prior to 
sample storage or preparation. Sometimes these substances can also be combined with buffers or organic solvents such as methanol and acetonitrile [213-215]. The stability of L-ascorbic acid and dehydroascorbic acid in biological samples was studied in detail by Pullar et al. (2018) and Bernasconi et al. (2018) [216,217]. These authors pointed out, for example, the necessity of immediate separation of stabilized plasma from blood cells, the influence of hemolysis on ascorbate oxidation due to the release of catalytic iron from haemoglobin, and necessity to keep EDTA anticoagulant samples cold during handling.

Numerous methods for the determination of L-ascorbic acid in foods and pharmaceuticals have been published [218-221]. However, the determination of vitamin C in biological samples has not garnered further attention, likely because of its complexity. The most common biological materials used for its determination are serum, plasma, urine, red and white blood cells, breast milk, and sweat [222,223]. The recent methods include capillary electrophoresis, liquid chromatography, and electrochemical biosensors in addition to commercially available kits that can be used in routine applications. Some selected methods used for vitamin $C$ determination in human biofluids are presented in Table 3.

Due to its sensitivity and good selectivity, capillary electrophoresis (CE) coupled with electrochemical detection (ECD) has been one of the most widely used techniques in the determination of AA in biological samples. However, the high separation voltage could interfere with the electrochemical detection and the analysis of biomatrix samples could contaminate the electrode surface. These methods are only used in the determination of L-ascorbic acid because dehydroascorbic acid is electrochemically inactive [224].

Table 3. Summary of methods for determination of vitamin C in human biological materials.

\begin{tabular}{|c|c|c|c|c|}
\hline Technique & $\begin{array}{c}\text { Sensitivity } \\
\text { (AA in } \mu \mathrm{M} \text { if } \\
\text { not Specified) }\end{array}$ & Advantages & Disadvantages & References \\
\hline LC-UV/PDA & $\begin{array}{c}4.95 * \\
4.0 * \\
5.0 * * \\
31.81 *\end{array}$ & Commonly affordable technique, & $\begin{array}{l}\text { AA determination only (poor } \\
\text { absorption properties of DHA), }\end{array}$ & [211,225-227] \\
\hline LC-ECD & $\begin{array}{l}9 \times 10^{-2 *} \\
1.34 * \\
2.5 \times 10^{-2 *} \\
0.50^{*}\end{array}$ & $\begin{array}{l}\text { selectivity and sensitivity, easy } \\
\text { miniaturization }\end{array}$ & $\begin{array}{l}\text { DHA is electroinactive, contamination } \\
\text { of electrode by real samples }\end{array}$ & {$[226,228-230]$} \\
\hline LC-MS & $\begin{array}{c}0.5^{* *} \\
\text { DHA: } 5^{* *} \\
113^{* *}\end{array}$ & $\begin{array}{c}\text { selectivity, } \\
\text { possibility of simultaneous } \\
\text { determination of AA and DHA } \\
\text { possibility of labeled internal } \\
\text { standards usage }\end{array}$ & $\begin{array}{l}\text { Costly device, highly skilled personnel, } \\
\text { complicated DHA ionization }\end{array}$ & {$[213,214,231]$} \\
\hline CE-ECD & $\begin{array}{c}\text { CZE-ECD: } \\
1.7^{* * *} \\
0.49^{* * *} \\
0.50^{* * *}\end{array}$ & $\begin{array}{l}\text { Small sample and solvent volumes, } \\
\text { good sensitivity }\end{array}$ & $\begin{array}{c}\text { High separation voltage could interfere } \\
\text { with the detection of an } \\
\text { electrochemical signal, contamination } \\
\text { of electrode by real samples, DHA is } \\
\text { electroinactive }\end{array}$ & [224,232-234] \\
\hline CE-CL & $\begin{array}{l}\text { MCE-CL: } \\
1.3^{* * *} \\
\text { CZE-CL: } \\
0.01^{* * *}\end{array}$ & $\begin{array}{l}\text { Small sample and solvent volumes, } \\
\text { good sensitivity }\end{array}$ & $\begin{array}{l}\text { No natural luminescence of AA } \\
\text { (necessity of reaction with } \\
\text { luminol-AA enhancing effect), } \\
\text { contamination of electrode by } \\
\text { real samples }\end{array}$ & {$[232,235,236]$} \\
\hline CE-UV & $\begin{array}{l}\text { MEKC-UV: } \\
5.0 * * * \\
0.85^{* * *}\end{array}$ & Small sample and solvent volumes & $\begin{array}{c}\text { Low sensitivity, poor absorption } \\
\text { properties of DHA, AA } \\
\text { determination only }\end{array}$ & {$[232,237,238]$} \\
\hline
\end{tabular}


Table 3. Cont.

\begin{tabular}{|c|c|c|c|c|}
\hline Technique & $\begin{array}{c}\text { Sensitivity } \\
\text { (AA in } \mu \mathrm{M} \text { if } \\
\text { not Specified) }\end{array}$ & Advantages & Disadvantages & References \\
\hline biosensors & $\begin{array}{c}0.12^{* * *} \\
7.4 \times 10^{-2} * * * \\
8.5 \times 10^{-4 * * *} \\
5.0 \times 10^{-4 * * *} \\
0.02^{* * *} \\
5.68 \times 10^{-3 * * *} \\
9.0 \times 10^{-3 * * *} \\
13.5 \times 10^{-3 * *} \\
0.85 \times 10^{-3 * * *}\end{array}$ & $\begin{array}{l}\text { Small sample and solvent volumes, } \\
\text { low price, portable, good sensitivity, } \\
\text { possible to detect AA in vivo }\end{array}$ & $\begin{array}{l}\text { Mostly using ECD_-impossible to } \\
\text { detect DHA, not commercially } \\
\text { available, not tested for large biological } \\
\text { sample series }\end{array}$ & {$[239-247]$} \\
\hline HPLC-UV kits & $\begin{array}{l}2.84 \text { * } \\
2.27 \text { * }\end{array}$ & See LC-UV & See LC-UV, very high cost & {$[248,249]$} \\
\hline colorimetric/FLD kits & $\begin{array}{c}2.0 \times 10^{-4 * * *} \\
5.0 * * *(\mathrm{FLD}) \\
3.2^{* * *}\end{array}$ & $\begin{array}{l}\text { One kit usable for different matrices } \\
\text { (fluids, cells, tissues), commonly } \\
\text { available technique, small sample, } \\
\text { and solvent volumes, low } \\
\text { operation cost }\end{array}$ & $\begin{array}{c}\text { Impossible to differentiate AA and } \\
\text { DHA, suitable for large sample } \\
\text { series-expiration of the kit } \\
\text { after opening }\end{array}$ & {$[250-253]$} \\
\hline immunoassays kits & $\begin{array}{l}0.57^{* * *} \\
1.08^{* * *}\end{array}$ & $\begin{array}{l}\text { One kit usable for different matrices } \\
\text { (fluids, cells, tissues), commonly } \\
\text { available technique, small sample, } \\
\text { and solvent volumes, low } \\
\text { operation cost }\end{array}$ & $\begin{array}{c}\text { Cross-reactions, impossible to } \\
\text { differentiate AA and DHA, suitable for } \\
\text { large sample series-short expiration } \\
\text { of the kit after opening }\end{array}$ & {$[254,255]$} \\
\hline
\end{tabular}

${ }^{*}$ LOQ (limit of quantification), ${ }^{* *}$ LLOQ (lower limit of quantification), ${ }^{* * *}$ LOD (limit of detection). AA, ascorbic acid. DHA, dehydroascorbic acid. LC-UV/PDA, liquid chromatography with photodiode array/ultraviolet detection. FLD, fluorescence detection. LC-ECD, liquid chromatography with electrochemical detection. LC-CL, liquid chromatography with chemiluminescence detection. LC-MS, liquid chromatography with mass spectrometry detection. CE-ECD, capillary electrophoresis with electrochemical detection. CE-CL, capillary electrophoresis with chemiluminescence detection. CE-UV, capillary electrophoresis with ultraviolet detection. CZE-ECD, capillary zone electrophoresis with electrochemical detection. MCE-CL, microchip capillary electrophoresis with chemiluminescence detection. CZE-CL, capillary zone electrophoresis with chemiluminescence detection. MEKC-UV, micellar electrokinetic chromatography with ultraviolet detection. ECD, electrochemical detection. LC-UV, liquid chromatography with ultraviolet detection. HPLC-UV, high-performance liquid chromatography with ultraviolet detection.

The determination of vitamin C by high-performance liquid chromatography HPLC (highperformance liquid chromatography) was summarized in a review by Nováková et al., 2008, where the general aspects of chromatographic determination are summarized in detail [256].

UV (ultraviolet) and ECD (electrochemical detection) are the most common detection systems used in HPLC. Unfortunately, none of them enables the simultaneous detection of L-ascorbic and dehydroascorbic acid in a single run. The absorbance maximum of $\mathrm{L}$-ascorbic acid is in the range of $244-265 \mathrm{~nm}$ as a function of $\mathrm{pH}$. UV detection of dehydroascorbic acid requires its prior derivatization due to its poor absorption at a wavelength of $185 \mathrm{~nm}$. Unlike L-ascorbic acid, dehydroascorbic acid is electrochemically inactive and ECD detection is also not possible [256]. Fluorescent detection is not widely used because it requires an additional time-consuming derivatization step. The specific reaction of dehydroascorbic acid with dimethyl-o-phenylenediamine results in a fluorescent quinoxaline derivative that is quantified by HPLC [257]. Mass spectrometry (MS) detection has been rarely used, even though it enables the simultaneous detection of both substances. Only a few methods for the determination of DHA and AA in human fluids with MS detection were presented in the medical literature [214,231]. The difficulty of LC-MS method development is related to the matrix effect induced signal suppression, but other factors, such as non-standard ionization patterns, resulting in complex ion species and in-source interconversion play an important role. The MS detection is generally carried out in a negative mode with electrospray ionization $[213,214]$. Some MS detection methods use the subtraction approach in a similar manner to UV detection [231]. Typically, chromatographic methods carry out the separations in a reverse phase mode in which L-ascorbic and dehydroascorbic acids are poorly retained due to a very hydrophilic nature. A very low 
$\mathrm{pH}$ is needed to avoid degradation of AA in samples and to allow some retention. On the other hand, ion exchange, ion pair, and ion exclusion chromatography more suitable for retention of these polar species require either a complex mobile phase composition, including ion-pairing reagents, EDTA, or the presence of inorganic buffers, such as phosphate or borate buffers. All these reagents are incompatible with MS detection. On the other hand, hydrophilic interaction liquid chromatography (HILIC) would be very convenient to determine L-ascorbic acid. However, the bioanalytical results are rather scarce [225].

Extraction techniques for L-ascorbic and dehydroascorbic acids present in biomatrices applied prior to HPLC and CE (capillary electrophoresis) analysis are simple and mostly comprise dilution, protein precipitation, centrifugation, and filtration. The sample preparation can also be performed using solid phase extraction [237]. Since the target analytes can degrade during the sample preparation process, stabilizers and/or chelators need to be added to the sample $[223,226,228]$.

An internal standard is not routinely used to determine L-ascorbic acid in biological material because it is difficult to find a compound that is suitable for both extraction and analysis steps similar to L-ascorbic acid. For example, its stereoisomer iso-ascorbic acid (Figure 1B), has been used in bioanalysis. However, it can be naturally present in some biological samples. Other substances, such as tris(2-carboxyethyl)phosphine hydrochloride, have also been used, even though they can undergo similar redox reactions as L-ascorbic acid. Thus, internal standard quantification is difficult $[213,225]$. This problem can be solved by using stable isotopically-labelled internal standards during MS detection.

Electrochemical sensors are a vast area for the exploration of vitamin $C$ determination. Unfortunately, they were used for biological samples only to demonstrate the possibility of their use but not their application in routine practice. Nevertheless, they possess many advantages such as simplicity, cost-effectiveness, high sensitivity, easy miniaturization, reliability, and reproducibility. Moreover, the recent innovations in electrode nanomaterials improved both sensitivity and selectivity [239] and yielded one of the most sensitive techniques for L-ascorbic acid detection in biological materials. As a downside, the use of these sensors in routine practice or in large clinical studies has yet to be tested. In this regard, a cost-effective preparation of carbon quantum dots to determine $\mathrm{Fe}^{3+}$ ions and L-ascorbic acid detection in living cells showed a limit of detection of $196 \mathrm{nmol} / \mathrm{L}$ [258].

Finally, commercially available vitamin C kits are often used in routine and research clinical applications.

These commercial kits can be classified as follows.

1. HPLC-UV kits: These kits contain the chromatographic column, the mobile phase, the extraction reagents, and the control material. They are usually based on a reversephase mode and have higher selectivity and specificity than other types of L-ascorbic acid kits. However, they need complex instrumentation and are very expensive.

2. Colorimetric kits: They enable the detection of L-ascorbic acid in a wide range of biological fluids, tissues, and cells. They are available in 96-well or dipstick formats [250]. The determination is based on the chelation of ferrous iron with a colorimetric probe to produce a compound exhibiting a strong absorbance. The manufacturer of FRASC L-ascorbic acid Assay kit II claims a detection threshold of 0.2-20 nmol.

3. ELISA kits: A classical ELISA-type immunokit is based on antigen-antibody interaction. The competitive ELISA kits utilize a polyclonal anti-vitamin C antibody and a vitamin C-HRP conjugate. Their main disadvantage is the cost and the possible interaction with interferences that reduce the selectivity.

\section{Conclusions}

Vitamin C has become a very popular over-the-counter preparation mainly due to its claimed strengthening effects on immunity with preventive activity toward different infections, and possible effects on other diseases encompassing cardiovascular diseases and cancer. The latter are traditionally linked to its antioxidant properties, which have been repeatedly confirmed in vitro. It should be, however, mentioned, that vitamin $C$ can 
also behave as a prooxidant. This effect is apparent in high doses and seems to be the base for its possible use as an anti-cancer drug when given intravenously. Although there are also claims of its protective cardiovascular effects, definite proofs are missing. The protective effects of vitamin $C$ against different infections are generally low, but might be tangible in some specific conditions. Vitamin $C$ is an essential or optimal cofactor for many enzymes involved in several processes, including the correct formation of connective tissue and hormone synthesis. Recently, its role in several epigenetic processes was revealed. Future studies will likely specify the role of vitamin $C$ in more depth in these processes. In conclusion, vitamin $C$ is largely non-toxic, but its high doses should be avoided due to the rare but well-documented formation of kidney stones and rebound scurvy of new-borns.

Author Contributions: Conceptualization, P.M. Authors of chapters: Sources-K.M., Kinetics of vitamin C-P.M. and J.P. Physiological function.-E.J. and P.M. Vitamin C deficiency-P.M. Possible use of vitamin C in therapeutics-M.D. and P.M. Toxicity-P.M. and F.R. Determination of vitamin $\mathrm{C}$ in biological material-L.K.K., L.J., L.M., and L.N. Writing-original draft preparation, P.M., M.D., E.J., L.K.K., L.J., J.P., and K.M. Writing-review and editing, P.M., L.N., L.M., F.R., and M.D. Supervision, P.M. and L.N. Project administration, P.M. and L.N. Funding acquisition, P.M., L.N., and L.K.K. All authors have read and agreed to the published version of the manuscript.

Funding: This open-access review paper was supported by the Erasmus+ Programme of the European Union, Key Action 2: Strategic Partnerships, Project No. 2020-1-CZ01-KA203-078218. The authors also acknowledge the support of the EFSA-CDN project (CZ.02.1.01/0.0/0.0/16_019/0000841) co-funded by the ERDF. LKK and LJ thanks to MH CZ-DRO (UHHK, 00179906).

Acknowledgments: Open Access Educational Materials on Naturally Occurring Molecules (https: / /portal.faf.cuni.cz/OEMONOM/EN/).

Conflicts of Interest: The authors declare no conflict of interest.

\section{References}

1. Linster, C.L.; Van Schaftingen, E. Vitamin C. Biosynthesis, recycling and degradation in mammals. FEBS J. 2007, $274,1-22$. [CrossRef]

2. Granger, M.; Eck, P. Dietary vitamin C in human health. Adv. Food Nutr. Res. 2018, 83, 281-310. [CrossRef]

3. World Health Organization. Scurvy and its Prevention and Control in Major Emergencies/Prepared by Zita Weise Prinzo; World Health Organization: Geneva, Switzerland, 1999.

4. Englard, S.; Seifter, S. The biochemical functions of ascorbic acid. Annu. Rev. Nutr. 1986, 6, 365-406. [CrossRef]

5. Levine, M.; Rumsey, S.; Daruwala, R.; Park, J.; Wang, Y. Criteria and recommendations for vitamin C intake. JAMA 1999, 281, 1415-1423. [CrossRef]

6. Padayatty, S.J.; Levine, M. Vitamin C: The known and the unknown and Goldilocks. Oral. Dis. 2016, 22, 463-493. [CrossRef]

7. Sauberlich, H.E.; Tamura, T.; Craig, C.B.; Freeberg, L.E.; Liu, T. Effects of erythorbic acid on vitamin C metabolism in young women. Am. J. Clin. Nutr. 1996, 64, 336-346. [CrossRef] [PubMed]

8. Hornig, D. Distribution of ascorbic acid, metabolites and analogues in man and animals. Ann. N. Y. Acad. Sci. 1975, 258, 103-118. [CrossRef]

9. Robertson, W.B. D-Ascorbic acid and collagen synthesis. Biochim. Biophys. Acta 1963, 74, 137-139. [CrossRef]

10. Zilva, S.S. The behaviour of l-ascorbic acid and chemically related compounds in the animal body. The influence of generalised ether anaesthesia on their urinary excretion. Biochem. J. 1935, 29, 2366-2368. [CrossRef] [PubMed]

11. Davey, M.W.; Montagu, M.V.; Inzé, D.; Sanmartin, M.; Kanellis, A.; Smirnoff, N.; Benzie, I.J.J.; Strain, J.J.; Favell, D.; Fletcher, J. Plant L-ascorbic acid: Chemistry, function, metabolism, bioavailability and effects of processing. J. Sci. Food Agr. 2000, 80, 825-860. [CrossRef]

12. EFSA Panel on Dietetic Products, Nutrition and Allergies. Scientific opinion on dietary reference values for vitamin C. EFSA J. 2013, 11, 3418. [CrossRef]

13. Fediuk, K.; Hidiroglou, N.; Madère, R.; Kuhnlein, H.V. Vitamin C in Inuit traditional food and women's diets. J. Food Compos. Anal. 2002, 15, 221-235. [CrossRef]

14. Barros, L.; Ferreira, M.-J.; Queirós, B.; Ferreira, I.C.F.R.; Baptista, P. Total phenols, ascorbic acid, $\beta$-carotene and lycopene in Portuguese wild edible mushrooms and their antioxidant activities. Food Chem. 2007, 103, 413-419. [CrossRef]

15. Ferreira, I.; Barros, L.; Abreu, R. Antioxidants in wild mushrooms. Curr. Med. Chem. 2009, 16, 1543-1560. [CrossRef] [PubMed]

16. Mattila, P.; Könkö, K.; Eurola, M.; Pihlava, J.M.; Astola, J.; Vahteristo, L.; Hietaniemi, V.; Kumpulainen, J.; Valtonen, M.; Piironen, V. Contents of vitamins, mineral elements, and some phenolic compounds in cultivated mushrooms. J. Agric. Food Chem. 2001, 49, 2343-2348. [CrossRef] 
17. Williams, D.J.; Edwards, D.; Pun, S.; Chaliha, M.; Burren, B.; Tinggi, U.; Sultanbawa, Y. Organic acids in Kakadu plum (Terminalia ferdinandiana): The good (ellagic), the bad (oxalic) and the uncertain (ascorbic). Food Res. Int. 2016, 89, 237-244. [CrossRef] [PubMed]

18. Rodrigues, R.B.; De Menezes, H.C.; Cabral, L.M.C.; Dornier, M.; Reynes, M. An Amazonian fruit with a high potential as a natural source of vitamin C: The camu-camu (Myrciaria dubia). Fruits 2001, 56, 345-354. [CrossRef]

19. Mezadri, T.; Villaño, D.; Fernández-Pachón, M.S.; García-Parrilla, M.C.; Troncoso, A.M. Antioxidant compounds and antioxidant activity in acerola (Malpighia emarginata DC.) fruits and derivatives. J. Food Compos. Anal. 2008, 21, 282-290. [CrossRef]

20. Gutzeit, D.; Baleanu, G.; Winterhalter, P.; Jerz, G. Vitamin C content in sea buckthorn berries (Hippophaë rhamnoides L. ssp. rhamnoides) and related products: A kinetic study on storage stability and the determination of processing effects. J. Food Sci. 2008, 73, 615-620. [CrossRef] [PubMed]

21. Roman, I.; Stănilă, A.; Stănilă, S. Bioactive compounds and antioxidant activity of Rosa canina L. biotypes from spontaneous flora of Transylvania. Chem. Cent. J. 2013, 7, 73. [CrossRef]

22. Ariharan, V.N.; Kalirajan, K.; Devi, V.N.; Prasad, P. An exotic fruit which forms the new natural source for vitamin-C. Rasayan J. Chem. 2012, 5, 356 .

23. Gull, J.; Sultana, B.; Anwar, F.; Naseer, R.; Ashraf, M.; Ashrafuzzaman, M. Variation in antioxidant attributes at three ripening stages of guava (Psidium guajava L.) fruit from different geographical regions of Pakistan. Molecules 2012, 17, 3165-3180. [CrossRef] [PubMed]

24. Vagiri, M.; Ekholm, A.; Öberg, E.; Johansson, E.; Andersson, S.C.; Rumpunen, K. Phenols and ascorbic acid in black currants (Ribes nigrum L.): Variation due to genotype, location, and year. J. Agric. Food Chem. 2013, 61, 9298-9306. [CrossRef]

25. Ellong, E.; Billard, C.; Adenet, S.; Rochefort, K. Polyphenols, carotenoids, vitamin C content in tropical fruits and vegetables and impact of processing methods. Food Sci. Nutr. 2015, 6, 299-313. [CrossRef]

26. Domínguez-Perles, R.; Mena, P.; García-Viguera, C.; Moreno, D.A. Brassica foods as a dietary source of vitamin C: A review. Crit. Rev. Food Sci. Nutr. 2014, 54, 1076-1091. [CrossRef]

27. Martínez, S.; López, M.; González-Raurich, M.; Bernardo Alvarez, A. The effects of ripening stage and processing systems on vitamin C content in sweet peppers (Capsicum annuum L.). Int. J. Food Sci. Nutr. 2005, 56, 45-51. [CrossRef] [PubMed]

28. Peñas, E.; Frias, J.; Sidro, B.; Vidal-Valverde, C. Chemical evaluation and sensory quality of sauerkrauts obtained by natural and induced fermentations at different $\mathrm{NaCl}$ levels from Brassica oleracea Var. capitata Cv. Bronco grown in Eastern Spain. Effect of storage. J. Agric. Food Chem. 2010, 58, 3549-3557. [CrossRef]

29. Külen, O.; Stushnoff, C.; Holm, D.G. Effect of cold storage on total phenolics content, antioxidant activity and vitamin C level of selected potato clones. J. Sci. Food Agric. 2013, 93, 2437-2444. [CrossRef]

30. Santos, J.; Herrero, M.; Mendiola, J.; Oliva-Teles, M.T.; Ibáñez, E.; Delerue-Matos, C.; Oliveira, M. Fresh-cut aromatic herbs: Nutritional quality stability during shelf-life. LWT 2014, 59, 101-107. [CrossRef]

31. Chakraborty, S.; Santra, S. Biochemical composition of eight benthic alge collected from Sunderban. Indian J. Mar. Sci 2008, 37, 329-332.

32. Zheng, J.; Yang, B.; Tuomasjukka, S.; Ou, S.; Kallio, H. Effects of latitude and weather conditions on contents of sugars, fruit acids, and ascorbic acid in black currant (Ribes nigrum L.) juice. J. Agric. Food Chem. 2009, 57, 2977-2987. [CrossRef]

33. Kallio, H.; Yang, B.; Peippo, P. Effects of different origins and harvesting time on vitamin C, tocopherols, and tocotrienols in sea buckthorn (Hippophaë rhamnoides) berries. J. Agric. Food Chem. 2002, 50, 6136-6142. [CrossRef]

34. Cardoso, P.C.; Tomazini, A.P.B.; Stringheta, P.C.; Ribeiro, S.M.R.; Pinheiro-Sant'Ana, H.M. Vitamin C and carotenoids in organic and conventional fruits grown in Brazil. Food Chem. 2011, 126, 411-416. [CrossRef]

35. Raghu, V.; Platel, K.; Srinivasan, K. Comparison of ascorbic acid content of Emblica officinalis fruits determined by different analytical methods. J. Food Compos. Anal. 2007, 20, 529-533. [CrossRef]

36. Lešková, E.; Kubíková, J.; Kováčiková, E.; Košická, M.; Porubská, J.; Holčíková, K. Vitamin losses: Retention during heat treatment and continual changes expressed by mathematical models. J. Food Compos. Anal. 2006, 19, 252-276. [CrossRef]

37. Wang, J.; Law, C.L.; Mujumdar, A.S. The degradation mechanisms and kinetics of vitamin C in fruits and vegetables during thermal processing. In Drying Technologies in Foods; Nema, P.K., Kaur, B.P., Mujumdar, A.S., Eds.; CRC Press: Boca Raton, FL, USA, 2018; pp. 275-301.

38. Phillips, K.M.; Tarragó-Trani, M.T.; Gebhardt, S.E.; Exler, J.; Patterson, K.Y.; Haytowitz, D.B.; Pehrsson, P.R.; Holden, J.M. Stability of vitamin $C$ in frozen raw fruit and vegetable homogenates. J. Food Compos. Anal. 2010, 23, 253-259. [CrossRef]

39. Vandamme, E.J.; Revuelta, J.L. Industrial fermentation of vitamin C. In Industrial Biotechnology of Vitamins, Biopigments, and Antioxidants; Wiley-VCH Verlag GmbH \& Co. KGaA: Weinheim, Germany, 2016; pp. 161-192.

40. Carr, A.C.; Vissers, M.C. Synthetic or food-derived vitamin C-Are they equally bioavailable? Nutrients 2013, 5, 4284-4304. [CrossRef]

41. Konczak, I.; Maillot, F.; Dalar, A. Phytochemical divergence in 45 accessions of Terminalia ferdinandiana (Kakadu plum). Food Chem. 2014, 151, 248-256. [CrossRef]

42. Justi, K.C.; Visentainer, J.V.; Evelázio de Souza, N.; Matsushita, M. Nutritional composition and vitamin C stability in stored camu-camu (Myrciaria dubia) pulp. Arch. Latinoam. Nutr. 2000, 50, 405-408.

43. McCook-Russell, K.P.; Nair, M.G.; Facey, P.C.; Bowen-Forbes, C.S. Nutritional and nutraceutical comparison of Jamaican Psidium cattleianum (strawberry guava) and Psidium guajava (common guava) fruits. Food Chem. 2012, 134, 1069-1073. [CrossRef] 
44. Najwa, R.; Azlan, A. Comparison of vitamin C content in citrus fruits by titration and high performance liquid chromatography (HPLC) methods. Int. Food Res. J. 2017, 24, 726-733.

45. Njoku, P.C.; Ayuk, A.A.; Okoye, C.V. Temperature effects on vitamin C content in citrus fruits. Pak. J. Nutr. 2011, 10, 1168-1169. [CrossRef]

46. Kevers, C.; Pincemail, J.; Tabart, J.; Defraigne, J.O.; Dommes, J. Influence of cultivar, harvest time, storage conditions, and peeling on the antioxidant capacity and phenolic and ascorbic acid contents of apples and pears. J. Agric. Food Chem. 2011, 59, 6165-6171. [CrossRef] [PubMed]

47. Roberts, P.; Jones, D.L.; Edwards-Jones, G. Yield and vitamin C content of tomatoes grown in vermicomposted wastes. J. Sci. Food Agric. 2007, 87, 1957-1963. [CrossRef]

48. Georgé, S.; Tourniaire, F.; Gautier, H.; Goupy, P.; Rock, E.; Caris-Veyrat, C. Changes in the contents of carotenoids, phenolic compounds and vitamin $\mathrm{C}$ during technical processing and lyophilisation of red and yellow tomatoes. Food Chem. 2011, 124, 1603-1611. [CrossRef]

49. Turkben, C.; Uylaser, V.; Incedayi, B.; Çelikkol, I. Effects of different maturity periods and processes on nutritional components of rose hip (Rosa canina L.). J. Food Agric. Environ. 2010, 8, 26-30.

50. Singh, G.; Kawatra, A.; Sehgal, S. Nutritional composition of selected green leafy vegetables, herbs and carrots. Plant. Foods Hum. Nutr. 2001, 56, 359-364. [CrossRef] [PubMed]

51. Daruwala, R.; Song, J.; Koh, W.S.; Rumsey, S.C.; Levine, M. Cloning and functional characterization of the human sodiumdependent vitamin C transporters hSVCT1 and hSVCT2. FEBS Lett. 1999, 460, 480-484. [CrossRef]

52. Lykkesfeldt, J.; Tveden-Nyborg, P. The pharmacokinetics of vitamin C. Nutrients 2019, 11, 2412. [CrossRef]

53. Burzle, M.; Suzuki, Y.; Ackermann, D.; Miyazaki, H.; Maeda, N.; Clemencon, B.; Burrier, R.; Hediger, M.A. The sodium-dependent ascorbic acid transporter family SLC23. Mol. Aspects Med. 2013, 34, 436-454. [CrossRef]

54. Liang, W.J.; Johnson, D.; Jarvis, S.M. Vitamin C transport systems of mammalian cells. Mol. Membr. Biol. 2001, 18, 87-95. [CrossRef] [PubMed]

55. Levine, M.; Conry-Cantilena, C.; Yh, W.; Welch, R.; Washko, P.; Dhariwal, K.; Park, J.; Lazarev, A.; Graumlich, J.; King, J.; et al. Vitamin C pharmacokinetics in healthy volunteers: Evidence for a recommended dietary allowance. Proc. Natl. Acad. Sci. USA 1996, 93, 3704-3709. [CrossRef] [PubMed]

56. Hornig, D.; Vuilleumier, J.P.; Hartmann, D. Absorption of large, single, oral intakes of ascorbic acid. Int. J. Vitam. Nutr. Res. 1980, $50,309-314$.

57. Graumlich, J.F.; Ludden, T.M.; Conry-Cantilena, C.; Cantilena, L.R., Jr.; Wang, Y.; Levine, M. Pharmacokinetic model of ascorbic acid in healthy male volunteers during depletion and repletion. Pharm. Res. 1997, 14, 1133-1139. [CrossRef] [PubMed]

58. Kim, Y.; Kim, M.-G. HPLC-UV method for the simultaneous determinations of ascorbic acid and dehydroascorbic acid in human plasma. Transl. Clin. Pharmacol. 2016, 24, 37-42. [CrossRef]

59. Huijskens, M.J.; Wodzig, W.K.; Walczak, M.; Germeraad, W.T.; Bos, G.M. Ascorbic acid serum levels are reduced in patients with hematological malignancies. Results Immunol. 2016, 6, 8-10. [CrossRef] [PubMed]

60. Riemersma, R.A.; Carruthers, K.F.; Elton, R.A.; Fox, K.A. Vitamin C and the risk of acute myocardial infarction. Am. J. Clin. Nutr. 2000, 71, 1181-1186. [CrossRef]

61. Schleicher, R.L.; Carroll, M.D.; Ford, E.S.; Lacher, D.A. Serum vitamin C and the prevalence of vitamin C deficiency in the United States: 2003-2004 National Health and Nutrition Examination Survey (NHANES). Am. J. Clin. Nutr. 2009, 90, 1252-1263. [CrossRef] [PubMed]

62. Dhariwal, K.R.; Hartzell, W.O.; Levine, M. Ascorbic acid and dehydroascorbic acid measurements in human plasma and serum. Am. J. Clin. Nutr. 1991, 54, 712-716. [CrossRef] [PubMed]

63. Motoyama, T.; Kawano, H.; Kugiyama, K.; Hirashima, O.; Ohgushi, M.; Yoshimura, M.; Ogawa, H.; Yasue, H. Endotheliumdependent vasodilation in the brachial artery is impaired in smokers: Effect of vitamin C. Am. J. Physiol. 1997, 273, 1644-1650. [CrossRef] [PubMed]

64. Padayatty, S.J.; Sun, H.; Wang, Y.; Riordan, H.D.; Hewitt, S.M.; Katz, A.; Wesley, R.A.; Levine, M. Vitamin C pharmacokinetics: Implications for oral and intravenous use. Ann. Intern. Med. 2004, 140, 533-537. [CrossRef]

65. Levine, M.; Padayatty, S.J.; Espey, M.G. Vitamin C: A concentration-function approach yields pharmacology and therapeutic discoveries. Adv. Nutr. 2011, 2, 78-88. [CrossRef] [PubMed]

66. Levine, M.; Wang, Y.; Padayatty, S.J.; Morrow, J. A new recommended dietary allowance of vitamin C for healthy young women. Proc. Natl. Acad. Sci. USA 2001, 98, 9842-9846. [CrossRef]

67. Chen, Q.; Espey, M.G.; Sun, A.Y.; Lee, J.H.; Krishna, M.C.; Shacter, E.; Choyke, P.L.; Pooput, C.; Kirk, K.L.; Buettner, G.R.; et al. Ascorbate in pharmacologic concentrations selectively generates ascorbate radical and hydrogen peroxide in extracellular fluid in vivo. Proc. Natl. Acad. Sci. USA 2007, 104, 8749-8754. [CrossRef] [PubMed]

68. May, J.M.; Harrison, F.E. Role of vitamin C in the function of the vascular endothelium. Antioxid. Redox Sign. 2013, 19, 2068-2083. [CrossRef]

69. Harrison, F.E.; Dawes, S.M.; Meredith, M.E.; Babaev, V.R.; Li, L.; May, J.M. Low vitamin C and increased oxidative stress and cell death in mice that lack the sodium-dependent vitamin C transporter SVCT2. Free Radic. Biol. Med. 2010, 49, 821-829. [CrossRef] 
70. Sotiriou, S.; Gispert, S.; Cheng, J.; Wang, Y.; Chen, A.; Hoogstraten-Miller, S.; Miller, G.F.; Kwon, O.; Levine, M.; Guttentag, S.H.; et al. Ascorbic-acid transporter Slc23a1 is essential for vitamin C transport into the brain and for perinatal survival. Nat. Med. 2002, 8, 514-517. [CrossRef]

71. May, J.M.; Qu, Z.C. Transport and intracellular accumulation of vitamin C in endothelial cells: Relevance to collagen synthesis. Arch. Biochem. Biophys. 2005, 434, 178-186. [CrossRef] [PubMed]

72. Prigge, S.T.; Mains, R.E.; Eipper, B.A.; Amzel, L.M. New insights into copper monooxygenases and peptide amidation: Structure, mechanism and function. Cell. Mol. Life Sci. 2000, 57, 1236-1259. [CrossRef] [PubMed]

73. May, J.M. Vitamin C transport and its role in the central nervous system. Subcell. Biochem. 2012, 56, 85-103. [CrossRef]

74. Corpe, C.; Lee, J.-H.; Kwon, O.; Eck, P.; Narayanan, J.; Kirk, K.; Levine, M. 6-Bromo-6-deoxy-L-ascorbic acid: An ascorbate analog specific for $\mathrm{Na}+$-dependent vitamin $\mathrm{C}$ transporter but not glucose transporter pathways. J. Biol. Chem. 2005, 280, 5211-5220. [CrossRef]

75. Tolbert, B.M.; Ward, J.B. Dehydroascorbic acid. In Ascorbic Acid: Chemistry, Metabolism, and Uses; Seib, P.A., Tolbert, B.M., Eds.; American Chemical Society: Washington, DC, USA, 1982; pp. 101-123.

76. Banhegyi, G.; Braun, L.; Csala, M.; Puskas, F.; Mandl, J. Ascorbate metabolism and its regulation in animals. Free Radic. Biol. Med. 1997, 23, 793-803. [CrossRef]

77. Huang, J.; Agus, D.B.; Winfree, C.J.; Kiss, S.; Mack, W.J.; McTaggart, R.A.; Choudhri, T.F.; Kim, L.J.; Mocco, J.; Pinsky, D.J.; et al. Dehydroascorbic acid, a blood-brain barrier transportable form of vitamin C, mediates potent cerebroprotection in experimental stroke. Proc. Natl. Acad. Sci. USA 2001, 98, 11720-11724. [CrossRef] [PubMed]

78. Schjoldager, J.G.; Paidi, M.D.; Lindblad, M.M.; Birck, M.M.; Kjærgaard, A.B.; Dantzer, V.; Lykkesfeldt, J.; Tveden-Nyborg, P. Maternal vitamin C deficiency during pregnancy results in transient fetal and placental growth retardation in guinea pigs. Eur. J. Nutr. 2015, 54, 667-676. [CrossRef] [PubMed]

79. Hellman, L.; Burns, J.J. Metabolism of L-ascorbic acid-1-C14 in man. J. Biol. Chem. 1958, 230, 923-930. [CrossRef]

80. Corpe, C.P.; Tu, H.; Eck, P.; Wang, J.; Faulhaber-Walter, R.; Schnermann, J.; Margolis, S.; Padayatty, S.; Sun, H.; Wang, Y.; et al. Vitamin C transporter Slc23a1 links renal reabsorption, vitamin C tissue accumulation, and perinatal survival in mice. J. Clin. Investig. 2010, 120, 1069-1083. [CrossRef]

81. Tsukaguchi, H.; Tokui, T.; Mackenzie, B.; Berger, U.V.; Chen, X.Z.; Wang, Y.; Brubaker, R.F.; Hediger, M.A. A family of mammalian $\mathrm{Na}$ +-dependent L-ascorbic acid transporters. Nature 1999, 399, 70-75. [CrossRef]

82. Timpson, N.J.; Forouhi, N.G.; Brion, M.J.; Harbord, R.M.; Cook, D.G.; Johnson, P.; McConnachie, A.; Morris, R.W.; Rodriguez, S.; Luan, J.; et al. Genetic variation at the SLC23A1 locus is associated with circulating concentrations of L-ascorbic acid (vitamin C): Evidence from 5 independent studies with $>15,000$ participants. Am. J. Clin. Nutr. 2010, 92, 375-382. [CrossRef]

83. Michels, A.J.; Hagen, T.M.; Frei, B. Human genetic variation influences vitamin $\mathrm{C}$ homeostasis by altering vitamin $\mathrm{C}$ transport and antioxidant enzyme function. Annu. Rev. Nutr. 2013, 33, 45-70. [CrossRef]

84. Erichsen, H.C.; Engel, S.A.; Eck, P.K.; Welch, R.; Yeager, M.; Levine, M.; Siega-Riz, A.M.; Olshan, A.F.; Chanock, S.J. Genetic variation in the sodium-dependent vitamin C transporters, SLC23A1, and SLC23A2 and risk for preterm delivery. Am. J. Epidemiol. 2006, 163, 245-254. [CrossRef]

85. Duell, E.J.; Lujan-Barroso, L.; Llivina, C.; Munoz, X.; Jenab, M.; Boutron-Ruault, M.C.; Clavel-Chapelon, F.; Racine, A.; Boeing, H.; Buijsse, B.; et al. Vitamin C transporter gene (SLC23A1 and SLC23A2) polymorphisms, plasma vitamin C levels, and gastric cancer risk in the EPIC cohort. Genes Nutr. 2013, 8, 549-560. [CrossRef]

86. Amir Shaghaghi, M.; Bernstein, C.N.; Serrano Leon, A.; El-Gabalawy, H.; Eck, P. Polymorphisms in the sodium-dependent ascorbate transporter gene SLC23A1 are associated with susceptibility to Crohn disease. Am. J. Clin. Nutr. 2014, 99, 378-383. [CrossRef]

87. Skibola, C.F.; Bracci, P.M.; Halperin, E.; Nieters, A.; Hubbard, A.; Paynter, R.A.; Skibola, D.R.; Agana, L.; Becker, N.; Tressler, P.; et al. Polymorphisms in the estrogen receptor 1 and vitamin $C$ and matrix metalloproteinase gene families are associated with susceptibility to lymphoma. PLoS ONE 2008, 3, e2816. [CrossRef] [PubMed]

88. De Jong, T.M.; Jochens, A.; Jockel-Schneider, Y.; Harks, I.; Dommisch, H.; Graetz, C.; Flachsbart, F.; Staufenbiel, I.; Eberhard, J.; Folwaczny, M.; et al. SLC23A1 polymorphism rs6596473 in the vitamin C transporter SVCT1 is associated with aggressive periodontitis. J. Clin. Periodontol. 2014, 41, 531-540. [CrossRef]

89. Wade, K.H.; Forouhi, N.G.; Cook, D.G.; Johnson, P.; McConnachie, A.; Morris, R.W.; Rodriguez, S.; Ye, Z.; Ebrahim, S.; Padmanabhan, S.; et al. Variation in the SLC23A1 gene does not influence cardiometabolic outcomes to the extent expected given its association with L-ascorbic acid. Am. J. Clin. Nutr. 2015, 101, 202-209. [CrossRef]

90. Wright, M.E.; Andreotti, G.; Lissowska, J.; Yeager, M.; Zatonski, W.; Chanock, S.J.; Chow, W.H.; Hou, L. Genetic variation in sodium-dependent ascorbic acid transporters and risk of gastric cancer in Poland. Eur. J. Cancer 2009, 45, 1824-1830. [CrossRef]

91. Erichsen, H.C.; Peters, U.; Eck, P.; Welch, R.; Schoen, R.E.; Yeager, M.; Levine, M.; Hayes, R.B.; Chanock, S. Genetic variation in sodium-dependent vitamin C transporters SLC23A1 and SLC23A2 and risk of advanced colorectal adenoma. Nutr. Cancer 2008, 60, 652-659. [CrossRef] [PubMed]

92. Chen, A.A.; Marsit, C.J.; Christensen, B.C.; Houseman, E.A.; McClean, M.D.; Smith, J.F.; Bryan, J.T.; Posner, M.R.; Nelson, H.H.; Kelsey, K.T. Genetic variation in the vitamin C transporter, SLC23A2, modifies the risk of HPV16-associated head and neck cancer. Carcinogenesis 2009, 30, 977-981. [CrossRef] [PubMed] 
93. Andrew, A.S.; Gui, J.; Sanderson, A.C.; Mason, R.A.; Morlock, E.V.; Schned, A.R.; Kelsey, K.T.; Marsit, C.J.; Moore, J.H.; Karagas, M.R. Bladder cancer SNP panel predicts susceptibility and survival. Hum. Genet. 2009, 125, 527-539. [CrossRef] [PubMed]

94. Casabonne, D.; Gracia, E.; Espinosa, A.; Bustamante, M.; Benavente, Y.; Robles, C.; Costas, L.; Alonso, E.; Gonzalez-Barca, E.; Tardon, A.; et al. Fruit and vegetable intake and vitamin C transporter gene (SLC23A2) polymorphisms in chronic lymphocytic leukaemia. Eur. J. Nutr. 2017, 56, 1123-1133. [CrossRef] [PubMed]

95. Zanon-Moreno, V.; Ciancotti-Olivares, L.; Asencio, J.; Sanz, P.; Ortega-Azorin, C.; Pinazo-Duran, M.D.; Corella, D. Association between a SLC23A2 gene variation, plasma vitamin C levels, and risk of glaucoma in a Mediterranean population. Mol. Vis. 2011, 17, 2997-3004.

96. Dalgard, C.; Christiansen, L.; Vogel, U.; Dethlefsen, C.; Tjonneland, A.; Overvad, K. Variation in the sodium-dependent vitamin C transporter 2 gene is associated with risk of acute coronary syndrome among women. PLoS ONE 2013, 8, e70421. [CrossRef]

97. McDonough, M.; Loenarz, C.; Chowdhury, R.; Clifton, I.; Schofield, C. Structural studies on human 2-oxoglutarate dependent oxygenases. Curr. Opin. Struct. Biol. 2010, 20, 659-672. [CrossRef] [PubMed]

98. Kuiper, C.; Vissers, M.C. Ascorbate as a co-factor for fe- and 2-oxoglutarate dependent dioxygenases: Physiological activity in tumor growth and progression. Front. Oncol. 2014, 4, 359. [CrossRef]

99. Loenarz, C.; Schofield, C.J. Physiological and biochemical aspects of hydroxylations and demethylations catalyzed by human 2-oxoglutarate oxygenases. Trends Biochem. Sci. 2011, 36, 7-18. [CrossRef]

100. Myllyla, R.; Kuutti-Savolainen, E.R.; Kivirikko, K.I. The role of ascorbate in the prolyl hydroxylase reaction. Biochem. Biophys. Res. Commun. 1978, 83, 441-448. [CrossRef]

101. Islam, M.S.; Leissing, T.; Chowdhury, R.; Hopkinson, R.; Schofield, C. 2-Oxoglutarate-dependent oxygenases. Annu. Rev. Biochem. 2018, 87. [CrossRef] [PubMed]

102. Young, J.I.; Zuchner, S.; Wang, G. Regulation of the epigenome by vitamin C. Annu. Rev. Nutr. 2015, 35, 545-564. [CrossRef]

103. Cimmino, L.; Neel, B.G.; Aifantis, I. Vitamin C in stem cell reprogramming and cancer. Trends Cell Biol. 2018, 28, 698-708. [CrossRef] [PubMed]

104. Vasta, J.D.; Raines, R.T. Collagen prolyl 4-hydroxylase as a therapeutic target. J. Med. Chem. 2018, 61, 10403-10411. [CrossRef] [PubMed]

105. Amer, J.; Zelig, O.; Fibach, E. Oxidative status of red blood cells, neutrophils, and platelets in paroxysmal nocturnal hemoglobinuria. Exp. Hematol. 2008, 36, 369-377. [CrossRef]

106. Furusawa, H.; Sato, Y.; Tanaka, Y.; Inai, Y.; Amano, A.; Iwama, M.; Kondo, Y.; Handa, S.; Murata, A.; Nishikimi, M.; et al. Vitamin $C$ is not essential for carnitine biosynthesis in vivo: Verification in vitamin C-depleted senescence marker protein30/gluconolactonase knockout mice. Biol. Pharm. Bull. 2008, 31, 1673-1679. [CrossRef] [PubMed]

107. Monfort, A.; Wutz, A. Breathing-in epigenetic change with vitamin C. EMBO Rep. 2013, 14, 337-346. [CrossRef]

108. Das, A.B.; Smith-Diaz, C.C.; Vissers, M.C.M. Emerging epigenetic therapeutics for myeloid leukemia: Modulating demethylase activity with ascorbate. Haematologica 2020, 106. [CrossRef] [PubMed]

109. Lee Chong, T.; Ahearn, E.L.; Cimmino, L. Reprogramming the epigenome with vitamin C. Front. Cell Dev. Biol. $2019,7,128$. [CrossRef] [PubMed]

110. Ozer, A.; Bruick, R.K. Non-heme dioxygenases: Cellular sensors and regulators jelly rolled into one? Nat. Chem. Biol. 2007, 3, 144-153. [CrossRef]

111. Kuiper, C.; Dachs, G.U.; Currie, M.J.; Vissers, M.C. Intracellular ascorbate enhances hypoxia-inducible factor (HIF)-hydroxylase activity and preferentially suppresses the HIF-1 transcriptional response. Free Radic. Biol. Med. 2014, 69, 308-317. [CrossRef] [PubMed]

112. Wang, T.; Chen, K.; Zeng, X.; Yang, J.; Wu, Y.; Shi, X.; Qin, B.; Zeng, L.; Esteban, M.A.; Pan, G.; et al. The histone demethylases Jhdm1a/1b enhance somatic cell reprogramming in a vitamin-C-dependent manner. Cell Stem. Cell 2011, 9, 575-587. [CrossRef]

113. Zhang, T.; Huang, K.; Zhu, Y.; Wang, T.; Shan, Y.; Long, B.; Li, Y.; Chen, Q.; Wang, P.; Zhao, S.; et al. Vitamin C-dependent lysine demethylase 6 (KDM6)-mediated demethylation promotes a chromatin state that supports the endothelial-to-hematopoietic transition. J. Biol. Chem. 2019, 294, 13657-13670. [CrossRef] [PubMed]

114. D'Oto, A.; Tian, Q.W.; Davidoff, A.M.; Yang, J. Histone demethylases and their roles in cancer epigenetics. J. Med. Oncol. Ther. 2016, 1, 34-40. [CrossRef]

115. Ge, W.; Wolf, A.; Feng, T.; Ho, C.H.; Sekirnik, R.; Zayer, A.; Granatino, N.; Cockman, M.E.; Loenarz, C.; Loik, N.D.; et al. Oxygenase-catalyzed ribosome hydroxylation occurs in prokaryotes and humans. Nat. Chem. Biol. 2012, 8, 960-962. [CrossRef]

116. Chowdhury, R.; Sekirnik, R.; Brissett, N.C.; Krojer, T.; Ho, C.H.; Ng, S.S.; Clifton, I.J.; Ge, W.; Kershaw, N.J.; Fox, G.C.; et al. Ribosomal oxygenases are structurally conserved from prokaryotes to humans. Nature 2014, 510, 422-426. [CrossRef]

117. Blaschke, K.; Ebata, K.T.; Karimi, M.M.; Zepeda-Martinez, J.A.; Goyal, P.; Mahapatra, S.; Tam, A.; Laird, D.J.; Hirst, M.; Rao, A.; et al. Vitamin C induces Tet-dependent DNA demethylation and a blastocyst-like state in ES cells. Nature 2013, 500, 222-226. [CrossRef]

118. Chen, J.; Guo, L.; Zhang, L.; Wu, H.; Yang, J.; Liu, H.; Wang, X.; Hu, X.; Gu, T.; Zhou, Z.; et al. Vitamin C modulates TET1 function during somatic cell reprogramming. Nat. Genet. 2013, 45, 1504-1509. [CrossRef]

119. Minor, E.A.; Court, B.L.; Young, J.I.; Wang, G. Ascorbate induces ten-eleven translocation (Tet) methylcytosine dioxygenasemediated generation of 5-hydroxymethylcytosine. J. Biol Chem. 2013, 288, 13669-13674. [CrossRef] [PubMed] 
120. Rasmussen, K.D.; Helin, K. Role of TET enzymes in DNA methylation, development, and cancer. Genes Dev. 2016, 30, 733-750. [CrossRef]

121. Zheng, G.; Dahl, J.A.; Niu, Y.; Fu, Y.; Klungland, A.; Yang, Y.G.; He, C. Sprouts of RNA epigenetics: The discovery of mammalian RNA demethylases. RNA Biol. 2013, 10, 915-918. [CrossRef] [PubMed]

122. Gerken, T.; Girard, C.A.; Tung, Y.C.; Webby, C.J.; Saudek, V.; Hewitson, K.S.; Yeo, G.S.; McDonough, M.A.; Cunliffe, S.; McNeill L.A.; et al. The obesity-associated FTO gene encodes a 2-oxoglutarate-dependent nucleic acid demethylase. Science 2007, 318, 1469-1472. [CrossRef] [PubMed]

123. Aas, P.A.; Otterlei, M.; Falnes, P.O.; Vagbo, C.B.; Skorpen, F.; Akbari, M.; Sundheim, O.; Bjoras, M.; Slupphaug, G.; Seeberg, E.; et al. Human and bacterial oxidative demethylases repair alkylation damage in both RNA and DNA. Nature 2003, 421, 859-863. [CrossRef]

124. Ougland, R.; Rognes, T.; Klungland, A.; Larsen, E. Non-homologous functions of the AlkB homologs. J. Mol. Cell Biol. 2015, 7, 494-504. [CrossRef]

125. Ueda, Y.; Ooshio, I.; Fusamae, Y.; Kitae, K.; Kawaguchi, M.; Jingushi, K.; Hase, H.; Harada, K.; Hirata, K.; Tsujikawa, K. AlkB homolog 3-mediated tRNA demethylation promotes protein synthesis in cancer cells. Sci. Rep. 2017, 7, 42271. [CrossRef]

126. Zou, S.; Toh, J.D.; Wong, K.H.; Gao, Y.G.; Hong, W.; Woon, E.C. N(6)-Methyladenosine: A conformational marker that regulates the substrate specificity of human demethylases FTO and ALKBH5. Sci. Rep. 2016, 6, 25677. [CrossRef]

127. Hudson, D.M.; Eyre, D.R. Collagen prolyl 3-hydroxylation: A major role for a minor post-translational modification? Connect. Tissue Res. 2013, 54, 245-251. [CrossRef] [PubMed]

128. Trackman, P.C. Enzymatic and non-enzymatic functions of the lysyl oxidase family in bone. Matrix Biol. 2016, 52-54, 7-18. [CrossRef]

129. Qi, Y.; Xu, R. Roles of PLODs in Collagen Synthesis and Cancer Progression. Front. Cell Dev. Biol. 2018, 6. [CrossRef]

130. Hirota, K.; Semenza, G.L. Regulation of hypoxia-inducible factor 1 by prolyl and asparaginyl hydroxylases. Biochem. Biophys. Res. Commun. 2005, 338, 610-616. [CrossRef] [PubMed]

131. Strowitzki, M.J.; Cummins, E.P.; Taylor, C.T. Protein hydroxylation by hypoxia-inducible factor (HIF) hydroxylases: Unique or ubiquitous? Cells 2019, 8, 384. [CrossRef] [PubMed]

132. Keith, B.; Simon, M.C. Hypoxia-inducible factors, stem cells, and cancer. Cell 2007, 129, 465-472. [CrossRef]

133. Lando, D.; Peet, D.J.; Gorman, J.J.; Whelan, D.A.; Whitelaw, M.L.; Bruick, R.K. FIH-1 is an asparaginyl hydroxylase enzyme that regulates the transcriptional activity of hypoxia-inducible factor. Genes Dev. 2002, 16, 1466-1471. [CrossRef] [PubMed]

134. Feng, T.; Yamamoto, A.; Wilkins, S.E.; Sokolova, E.; Yates, L.A.; Münzel, M.; Singh, P.; Hopkinson, R.J.; Fischer, R.; Cockman, M.E.; et al. Optimal translational termination requires C4 lysyl hydroxylation of eRF1. Mol. Cell 2014, 53, 645-654. [CrossRef]

135. Plch, J.; Hrabeta, J.; Eckschlager, T. KDM5 demethylases and their role in cancer cell chemoresistance. Int. J. Cancer 2019, 144, 221-231. [CrossRef]

136. Lan, F.; Bayliss, P.E.; Rinn, J.L.; Whetstine, J.R.; Wang, J.K.; Chen, S.; Iwase, S.; Alpatov, R.; Issaeva, I.; Canaani, E.; et al. A histone H3 lysine 27 demethylase regulates animal posterior development. Nature 2007, 449, 689-694. [CrossRef] [PubMed]

137. Schulz, W.A.; Lang, A.; Koch, J.; Greife, A. The histone demethylase UTX/KDM6A in cancer: Progress and puzzles. Int. J. Cancer 2019, 145, 614-620. [CrossRef]

138. Chaturvedi, S.S.; Ramanan, R.; Lehnert, N.; Schofield, C.J.; Karabencheva-Christova, T.G.; Christov, C.Z. Catalysis by the non-heme iron(II) histone demethylase PHF8 involves iron center rearrangement and conformational modulation of substrate orientation. ACS Catal. 2020, 10, 1195-1209. [CrossRef]

139. Wang, C.; Zhang, Q.; Hang, T.; Tao, Y.; Ma, X.; Wu, M.; Zhang, X.; Zang, J. Structure of the JmjC domain-containing protein NO66 complexed with ribosomal protein Rp18. Acta Crystallogr. D Biol. Crystallogr. 2015, 71, 1955-1964. [CrossRef] [PubMed]

140. Pandey, D.; Mohammad, F.; Weissmann, S.; Hallenborg, P.; Blagoev, B.; Helin, K. P11.36 Ribosome hydroxylase Mina53 is required for Glioblastoma and is involved in regulation of translation rateand fidelity by regulating ribosomal biogenesis. Neuro-Oncology 2019, 21, iii51. [CrossRef]

141. Rebouche, C.J. Kinetics, pharmacokinetics, and regulation of L-carnitine and acetyl-L-carnitine metabolism. Ann. N. Y. Acad. Sci. 2004, 1033, 30-41. [CrossRef] [PubMed]

142. Tars, K.; Rumnieks, J.; Zeltins, A.; Kazaks, A.; Kotelovica, S.; Leonciks, A.; Sharipo, J.; Viksna, A.; Kuka, J.; Liepinsh, E.; et al. Crystal structure of human gamma-butyrobetaine hydroxylase. Biochem. Biophys. Res. Commun. 2010, 398, 634-639. [CrossRef] [PubMed]

143. Wang, Y.; Reddy, Y.V.; Al Temimi, A.H.K.; Venselaar, H.; Nelissen, F.H.T.; Lenstra, D.C.; Mecinović, J. Investigating the active site of human trimethyllysine hydroxylase. Biochem. J. 2019, 476, 1109-1119. [CrossRef]

144. Moran, G.R. 4-Hydroxyphenylpyruvate dioxygenase. Arch. Biochem. Biophys. 2005, 433, 117-128. [CrossRef]

145. Vendelboe, T.V.; Harris, P.; Zhao, Y.; Walter, T.S.; Harlos, K.; El Omari, K.; Christensen, H.E.M. The crystal structure of human dopamine $\beta$-hydroxylase at $2.9 \AA$ resolution. Sci. Adv. 2016, 2, e1500980. [CrossRef]

146. Goldstein, M.; Fuxe, K.; Hokfelt, T. Characterization and tissue localization of catecholamine synthesizing enzymes. Pharmacol. Rev. 1972, 24, 293-309. [PubMed]

147. Eipper, B.A.; Milgram, S.L.; Husten, E.J.; Yun, H.Y.; Mains, R.E. Peptidylglycine alpha-amidating monooxygenase: A multifunctional protein with catalytic, processing, and routing domains. Protein Sci. 1993, 2, 489-497. [CrossRef] 
148. Kolhekar, A.S.; Mains, R.E.; Eipper, B.A. Peptidylglycine alpha-amidating monooxygenase: An ascorbate-requiring enzyme. Methods Enzymol. 1997, 279, 35-43. [CrossRef] [PubMed]

149. Bousquet-Moore, D.; Mains, R.E.; Eipper, B.A. Peptidylgycine $\alpha$-amidating monooxygenase and copper: A gene-nutrient interaction critical to nervous system function. J. Neurosci. Res. 2010, 88, 2535-2545. [CrossRef]

150. Martínez, A.; Montuenga, L.; Springall, D.; Treston, A.; Cuttitta, F.; Polak, J. Immunocytochemical localization of peptidylglycine alpha-amidating monooxygenase enzymes (PAM) in human endocrine pancreas. J. Histochem. Cytochem. 1993, 41, 375-380. [CrossRef]

151. Braas, K.M.; Harakall, S.A.; Ouafik, L.; Eipper, B.A.; May, V. Expression of peptidylglycine alpha-amidating monooxygenase: An in situ hybridization and immunocytochemical study. Endocrinology 1992, 130, 2778-2788. [CrossRef]

152. Morris, K.M.; Cao, F.; Onagi, H.; Altamore, T.M.; Gamble, A.B.; Easton, C.J. Prohormone-substrate peptide sequence recognition by peptidylglycine $\alpha$-amidating monooxygenase and its reflection in increased glycolate inhibitor potency. Bioorg. Med. Chem. Lett. 2012, 22, 7015-7018. [CrossRef]

153. Jeng, A.Y.; Fujimoto, R.A.; Chou, M.; Tan, J.; Erion, M.D. Suppression of substance P biosynthesis in sensory neurons of dorsal root ganglion by prodrug esters of potent peptidylglycine alpha-amidating monooxygenase inhibitors. J. Biol. Chem. 1997, 272, 14666-14671. [CrossRef] [PubMed]

154. Padayatty, S.J.; Katz, A.; Wang, Y.; Eck, P.; Kwon, O.; Lee, J.H.; Chen, S.; Corpe, C.; Dutta, A.; Dutta, S.K.; et al. Vitamin C as an antioxidant: Evaluation of its role in disease prevention. J. Am. Coll. Nutr. 2003, 22, 18-35. [CrossRef] [PubMed]

155. Gaut, J.P.; Belaaouaj, A.; Byun, J.; Roberts, L.J., 2nd.; Maeda, N.; Frei, B.; Heinecke, J.W. Vitamin C fails to protect amino acids and lipids from oxidation during acute inflammation. Free Radic. Biol. Med. 2006, 40, 1494-1501. [CrossRef]

156. Johnston, C.S.; Cox, S.K. Plasma-Saturating intakes of vitamin C confer maximal antioxidant protection to plasma. J. Am. Coll. Nutr. 2001, 20, 623-627. [CrossRef] [PubMed]

157. Carr, A.C.; Maggini, S. Vitamin C and immune function. Nutrients 2017, 9, 1211. [CrossRef] [PubMed]

158. Mortensen, A.; Lykkesfeldt, J. Does vitamin C enhance nitric oxide bioavailability in a tetrahydrobiopterin-dependent manner? In vitro, in vivo and clinical studies. Nitric Oxide. 2014, 36, 51-57. [CrossRef]

159. Oudemans-van Straaten, H.M.; Spoelstra-de Man, A.M.; de Waard, M.C. Vitamin C revisited. Crit. Care 2014, 18, 460. [CrossRef] [PubMed]

160. Förstermann, U.; Sessa, W.C. Nitric oxide synthases: Regulation and function. Eur. Heart J. 2012, 33, 829-837d. [CrossRef]

161. Kim, H.-L.; Park, Y. Maintenance of cellular tetrahydrobiopterin homeostasis. BMB Rep. 2010, 43, 584-592. [CrossRef]

162. Vasquez-Vivar, J.; Whitsett, J.; Martasek, P.; Hogg, N.; Kalyanaraman, B. Reaction of tetrahydrobiopterin with superoxide: EPR-kinetic analysis and characterization of the pteridine radical. Free Radic. Biol. Med. 2001, 31, 975-985. [CrossRef]

163. Wu, F.; Tyml, K.; Wilson, J.X. Ascorbate inhibits iNOS expression in endotoxin- and IFN gamma-stimulated rat skeletal muscle endothelial cells. FEBS Lett. 2002, 520, 122-126. [CrossRef]

164. Gokce, N.; Keaney, J.F., Jr.; Frei, B.; Holbrook, M.; Olesiak, M.; Zachariah, B.J.; Leeuwenburgh, C.; Heinecke, J.W.; Vita, J.A. Long-term ascorbic acid administration reverses endothelial vasomotor dysfunction in patients with coronary artery disease. Circulation 1999, 99, 3234-3240. [CrossRef]

165. Bassenge, E.; Fink, N.; Skatchkov, M.; Fink, B. Dietary supplement with vitamin C prevents nitrate tolerance. J. Clin. Investig. 1998, 102, 67-71. [CrossRef]

166. Seo, M.Y.; Lee, S.M. Protective effect of low dose of ascorbic acid on hepatobiliary function in hepatic ischemia/reperfusion in rats. J. Hepatol. 2002, 36, 72-77. [CrossRef]

167. Jackson, T.S.; Xu, A.; Vita, J.A.; Keaney, J.F., Jr. Ascorbate prevents the interaction of superoxide and nitric oxide only at very high physiological concentrations. Circ. Res. 1998, 83, 916-922. [CrossRef] [PubMed]

168. Podmore, I.D.; Griffiths, H.R.; Herbert, K.E.; Mistry, N.; Mistry, P.; Lunec, J. Vitamin C exhibits pro-oxidant properties. Nature 1998, 392, 559. [CrossRef] [PubMed]

169. Aronovitch, J.; Godinger, D.; Samuni, A.; Czapski, G. Ascorbic acid oxidation and DNA scission catalyzed by iron and copper chelates. Free Radic. Res. Commun. 1987, 2, 241-258. [CrossRef]

170. Hodges, R.E.; Hood, J.; Canham, J.E.; Sauberlich, H.E.; Baker, E.M. Clinical manifestations of ascorbic acid deficiency in man. Am. J. Clin. Nutr. 1971, 24, 432-443. [CrossRef] [PubMed]

171. Bird, T.A.; Schwartz, N.B.; Peterkofsky, B. Mechanism for the decreased biosynthesis of cartilage proteoglycan in the scorbutic guinea pig. J. Biol. Chem. 1986, 261, 11166-11172. [CrossRef]

172. Fukushima, R.; Yamazaki, E. Vitamin C requirement in surgical patients. Curr. Opin. Clin. Nutr. Metab. Care 2010, 13, 669-676. [CrossRef] [PubMed]

173. Long, C.L.; Maull, K.I.; Krishnan, R.S.; Laws, H.L.; Geiger, J.W.; Borghesi, L.; Franks, W.; Lawson, T.C.; Sauberlich, H.E. Ascorbic acid dynamics in the seriously ill and injured. J. Surg. Res. 2003, 109, 144-148. [CrossRef]

174. Padayatty, S.J.; Levine, M. Vitamin C and myocardial infarction: The heart of the matter. Am. J. Clin. Nutr. 2000, 71, 1027-1028. [CrossRef]

175. Mayland, C.R.; Bennett, M.I.; Allan, K. Vitamin C deficiency in cancer patients. Palliat. Med. 2005, 19, 17-20. [CrossRef]

176. Leveque, N.; Robin, S.; Muret, P.; Mac-Mary, S.; Makki, S.; Humbert, P. High iron and low ascorbic acid concentrations in the dermis of atopic dermatitis patients. Dermatology 2003, 207, 261-264. [CrossRef] 
177. Ngo, B.; Van Riper, J.M.; Cantley, L.C.; Yun, J. Targeting cancer vulnerabilities with high-dose vitamin C. Nat. Rev. Cancer 2019, 19, 271-282. [CrossRef]

178. Creagan, E.T.; Moertel, C.G.; O’Fallon, J.R.; Schutt, A.J.; O'Connell, M.J.; Rubin, J.; Frytak, S. Failure of high-dose vitamin C (ascorbic acid) therapy to benefit patients with advanced cancer. A controlled trial. N. Engl. J. Med. 1979, 301, 687-690. [CrossRef]

179. Moertel, C.G.; Fleming, T.R.; Creagan, E.T.; Rubin, J.; O'Connell, M.J.; Ames, M.M. High-dose vitamin C versus placebo in the treatment of patients with advanced cancer who have had no prior chemotherapy. A randomized double-blind comparison. $N$. Engl. J. Med. 1985, 312, 137-141. [CrossRef] [PubMed]

180. Chen, Q.; Espey, M.G.; Krishna, M.C.; Mitchell, J.B.; Corpe, C.P.; Buettner, G.R.; Shacter, E.; Levine, M. Pharmacologic ascorbic acid concentrations selectively kill cancer cells: Action as a pro-drug to deliver hydrogen peroxide to tissues. Proc. Natl. Acad. Sci. USA 2005, 102, 13604-13609. [CrossRef] [PubMed]

181. Chen, Q.; Espey, M.G.; Sun, A.Y.; Pooput, C.; Kirk, K.L.; Krishna, M.C.; Khosh, D.B.; Drisko, J.; Levine, M. Pharmacologic doses of ascorbate act as a prooxidant and decrease growth of aggressive tumor xenografts in mice. Proc. Natl. Acad. Sci. USA 2008, 105, 11105-11109. [CrossRef] [PubMed]

182. Fritz, H.; Flower, G.; Weeks, L.; Cooley, K.; Callachan, M.; McGowan, J.; Skidmore, B.; Kirchner, L.; Seely, D. Intravenous vitamin C and cancer: A systematic review. Integr. Cancer Ther. 2014, 13, 280-300. [CrossRef] [PubMed]

183. Nauman, G.; Gray, J.C.; Parkinson, R.; Levine, M.; Paller, C.J. Systematic review of intravenous ascorbate in cancer clinical trials. Antioxidants 2018, 7, 89. [CrossRef]

184. Klimant, E.; Wright, H.; Rubin, D.; Seely, D.; Markman, M. Intravenous vitamin C in the supportive care of cancer patients: A review and rational approach. Curr. Oncol. 2018, 25, 139-148. [CrossRef]

185. Perrone, G.; Hideshima, T.; Ikeda, H.; Okawa, Y.; Calabrese, E.; Gorgun, G.; Santo, L.; Cirstea, D.; Raje, N.; Chauhan, D.; et al. Ascorbic acid inhibits antitumor activity of bortezomib in vivo. Leukemia 2009, 23, 1679-1686. [CrossRef]

186. Luo, J.; Shen, L.; Zheng, D. Association between vitamin C intake and lung cancer: A dose-response meta-analysis. Sci. Rep. 2014, 4, 6161. [CrossRef]

187. Xu, X.; Yu, E.; Liu, L.; Zhang, W.; Wei, X.; Gao, X.; Song, N.; Fu, C. Dietary intake of vitamins A, C, and E and the risk of colorectal adenoma: A meta-analysis of observational studies. Eur. J. Cancer Prev. 2013, 22, 529-539. [CrossRef] [PubMed]

188. Bandera, E.V.; Gifkins, D.M.; Moore, D.F.; McCullough, M.L.; Kushi, L.H. Antioxidant vitamins and the risk of endometrial cancer: A dose-response meta-analysis. Cancer Causes Control. 2009, 20, 699-711. [CrossRef]

189. Moser, M.A.; Chun, O.K. Vitamin C and Heart Health: A review based on findings from epidemiologic studies. Int. J. Mol. Sci. 2016, 17. [CrossRef] [PubMed]

190. Ashor, A.W.; Brown, R.; Keenan, P.D.; Willis, N.D.; Siervo, M.; Mathers, J.C. Limited evidence for a beneficial effect of vitamin C supplementation on biomarkers of cardiovascular diseases: An umbrella review of systematic reviews and meta-analyses. Nutr. Res. 2019, 61, 1-12. [CrossRef] [PubMed]

191. Hemila, H. Vitamin C in clinical therapeutics. Clin. Ther. 2017, 39, 2110-2112. [CrossRef]

192. Shi, R.; Li, Z.H.; Chen, D.; Wu, Q.C.; Zhou, X.L.; Tie, H.T. Sole and combined vitamin C supplementation can prevent postoperative atrial fibrillation after cardiac surgery: A systematic review and meta-analysis of randomized controlled trials. Clin. Cardiol. 2018, 41, 871-878. [CrossRef]

193. Hemilä, H.; Suonsyrjä, T. Vitamin C for preventing atrial fibrillation in high risk patients: A systematic review and meta-analysis. BMC Cardiovasc. Disord. 2017, 17, 49. [CrossRef] [PubMed]

194. Putzu, A.; Daems, A.M.; Lopez-Delgado, J.C.; Giordano, V.F.; Landoni, G. The Effect of vitamin C on clinical outcome in critically ill patients: A systematic review with meta-analysis of randomized controlled trials. Crit. Care Med. 2019, 47, 774-783. [CrossRef]

195. Hemila, H. Vitamin C and infections. Nutrients 2017, 9, 339. [CrossRef]

196. Hemila, H.; Chalker, E. Vitamin C for preventing and treating the common cold. Cochrane Database Syst. Rev. 2013. [CrossRef] [PubMed]

197. Padhani, Z.A.; Moazzam, Z.; Ashraf, A.; Bilal, H.; Salam, R.A.; Das, J.K.; Bhutta, Z.A. Vitamin C supplementation for prevention and treatment of pneumonia. Cochrane Database Syst. Rev. 2020, 4. [CrossRef]

198. Hemila, H.; Louhiala, P. Vitamin C for preventing and treating pneumonia. Cochrane Database Syst. Rev. 2013. [CrossRef] [PubMed]

199. Fowler, A.A., 3rd.; Truwit, J.D.; Hite, R.D.; Morris, P.E.; DeWilde, C.; Priday, A.; Fisher, B.; Thacker, L.R., 2nd.; Natarajan, R.; Brophy, D.F.; et al. Effect of vitamin C infusion on organ failure and biomarkers of inflammation and vascular injury in patients with sepsis and severe acute respiratory failure: The CITRIS-ALI randomized clinical trial. JAMA 2019, 322, 1261-1270. [CrossRef]

200. Kuhn, S.O.; Meissner, K.; Mayes, L.M.; Bartels, K. Vitamin C in sepsis. Curr. Opin. Anaesthesiol. 2018, 31, 55-60. [CrossRef]

201. Jovic, T.H.; Ali, S.R.; Ibrahim, N.; Jessop, Z.M.; Tarassoli, S.P.; Dobbs, T.D.; Holford, P.; Thornton, C.A.; Whitaker, I.S. Could vitamins help in the fight against COVID-19? Nutrients 2020, 12, 2550. [CrossRef]

202. Carr, A.C.; Rowe, S. The emerging role of vitamin C in the prevention and treatment of COVID-19. Nutrients 2020, $12,3286$. [CrossRef]

203. Traxer, O.; Huet, B.; Poindexter, J.; Pak, C.Y.; Pearle, M.S. Effect of ascorbic acid consumption on urinary stone risk factors. J. Urol. 2003, 170, 397-401. [CrossRef] [PubMed]

204. Hung, K.C.; Lin, Y.T.; Chen, K.H.; Wang, L.K.; Chen, J.Y.; Chang, Y.J.; Wu, S.C.; Chiang, M.H.; Sun, C.K. The effect of perioperative vitamin $C$ on postoperative analgesic consumption: A meta-analysis of randomized controlled trials. Nutrients 2020, $12,3109$. [CrossRef] 
205. Robitaille, L.; Mamer, O.A.; Miller, W.H., Jr.; Levine, M.; Assouline, S.; Melnychuk, D.; Rousseau, C.; Hoffer, L.J. Oxalic acid excretion after intravenous ascorbic acid administration. Metabolism 2009, 58, 263-269. [CrossRef] [PubMed]

206. Padayatty, S.J.; Sun, A.Y.; Chen, Q.; Espey, M.G.; Drisko, J.; Levine, M. Vitamin C: Intravenous use by complementary and alternative medicine practitioners and adverse effects. PLoS ONE 2010, 5, e11414. [CrossRef]

207. Baxmann, A.C.; Mendonça, C.d.O.G.; Heilberg, I.P. Effect of vitamin $\mathrm{C}$ supplements on urinary oxalate and $\mathrm{pH}$ in calcium stone-forming patients. Kidney Int. 2003, 63, 1066-1071. [CrossRef]

208. Robertson, W.G.; Scurr, D.S.; Bridge, C.M. Factors influencing the crystallisation of calcium oxalate in urine-Critique. J. Cryst. Growth 1981, 53, 182-194. [CrossRef]

209. Taylor, E.N.; Stampfer, M.J.; Curhan, G.C. Dietary factors and the risk of incident kidney stones in men: New insights after 14 years of follow-up. J. Am. Soc. Nephrol. 2004, 15, 3225-3232. [CrossRef]

210. Iwamoto, N.; Kawaguchi, T.; Horikawa, K.; Nagakura, S.; Hidaka, M.; Kagimoto, T.; Takatsuki, K.; Nakakuma, H. Haemolysis induced by ascorbic acid in paroxysmal nocturnal haemoglobinuria. Lancet 1994, 343, 357. [CrossRef]

211. Karlsen, A.; Blomhoff, R.; Gundersen, T.E. High-throughput analysis of vitamin $C$ in human plasma with the use of HPLC with monolithic column and UV-detection. J. Chromatogr. B Analyt. Technol. Biomed. Life Sci. 2005, 824, 132-138. [CrossRef] [PubMed]

212. Ko, D.H.; Jeong, T.D.; Kim, S.; Chung, H.J.; Lee, W.; Chun, S.; Min, W.K. Influence of vitamin C on urine dipstick test results. Ann. Clin. Lab. Sci. 2015, 45, 391-395.

213. Nováková, L.; Solichová, D.; Pavlovicová, S.; Solich, P. Hydrophilic interaction liquid chromatography method for the determination of ascorbic acid. J. Sep. Sci. 2008, 31, 1634-1644. [CrossRef] [PubMed]

214. Szőcs, A.; Vancea, S.; Kiss, I.; Donáth-Nagy, G. Quantification of plasma and leukocyte vitamin C by high performance liquid chromatography with mass spectrometric detection. J. Anal. Chem. 2020, 75, 1168-1176. [CrossRef]

215. Lykkesfeldt, J. Ascorbate and dehydroascorbic acid as biomarkers of oxidative stress: Validity of clinical data depends on vacutainer system used. Nutr. Res. 2012, 32, 66-69. [CrossRef]

216. Pullar, J.M.; Bayer, S.; Carr, A.C. Appropriate handling, processing and analysis of blood samples is essential to avoid oxidation of vitamin $C$ to dehydroascorbic acid. Antioxidants 2018, 7, 29. [CrossRef]

217. Bernasconi, L.; Saxer, C.; Neyer, P.; Huber, A.; Steuer, C. Suitable preanalytical conditions for vitamin C measurement in clinical routine. J. Food Sci. Technol. 2018, 3, 280-287. [CrossRef]

218. Fatima, Z.; Jin, X.; Zou, Y.; Kaw, H.Y.; Quinto, M.; Li, D. Recent trends in analytical methods for water-soluble vitamins. J. Chromatogr. A 2019, 1606, 360245. [CrossRef]

219. Dos Santos, V.B.; da Silva, E.K.N.; de Oliveira, L.M.A.; Suarez, W.T. Low cost in situ digital image method, based on spot testing and smartphone images, for determination of ascorbic acid in Brazilian Amazon native and exotic fruits. Food Chem. 2019, 285, 340-346. [CrossRef]

220. Dhara, K.; Debiprosad, R.M. Review on nanomaterials-enabled electrochemical sensors for ascorbic acid detection. Anal. Biochem. 2019, 586, 113415. [CrossRef] [PubMed]

221. Spínola, V.; Llorent-Martínez, E.J.; Castilho, P.C. Determination of vitamin C in foods: Current state of method validation. J. Chromatogr. A 2014, 1369, 2-17. [CrossRef] [PubMed]

222. Sempionatto, J.R.; Khorshed, A.A.; Ahmed, A.; De Loyola, E.S.A.N.; Barfidokht, A.; Yin, L.; Goud, K.Y.; Mohamed, M.A.; Bailey, E.; May, J.; et al. Epidermal enzymatic biosensors for sweat vitamin C: Toward personalized nutrition. ACS Sens. 2020, 5, 1804-1813. [CrossRef] [PubMed]

223. Romeu-Nadal, M.; Morera-Pons, S.; Castellote, A.I.; López-Sabater, M.C. Rapid high-performance liquid chromatographic method for Vitamin C determination in human milk versus an enzymatic method. J. Chromatogr. B Analyt. Technol. Biomed. Life Sci. 2006, 830, 41-46. [CrossRef]

224. Wang, X.; Li, L.; Li, Z.; Wang, J.; Fu, H.; Chen, Z. Determination of ascorbic acid in individual liver cancer cells by capillary electrophoresis with a platinum nanoparticles modified electrode. J. Electroanal. Chem. 2014, 712, 139-145. [CrossRef]

225. Munday, M.R.; Rodricks, R.; Fitzpatrick, M.; Flood, V.M.; Gunton, J.E. A pilot study examining vitamin C levels in periodontal patients. Nutrients 2020, 12, 2255. [CrossRef] [PubMed]

226. Robitaille, L.; Hoffer, L.J. A simple method for plasma total vitamin C analysis suitable for routine clinical laboratory use. Nutr. J. 2016, 15, 40. [CrossRef] [PubMed]

227. Akbari, A.; Chamkouri, N.; Zadabdollah, A. Determination trace levels of vitamin C and folic acid in urine sample by ultrasoundassisted dispersive liquid-liquid microextraction method coupled HPLC-UV. Orient. J. Chem. 2016, 32. [CrossRef]

228. Gazdik, Z.; Zitka, O.; Petrlova, J.; Adam, V.; Zehnalek, J.; Horna, A.; Reznicek, V.; Beklova, M.; Kizek, R. Determination of vitamin $C$ (ascorbic acid) using high performance liquid chromatography coupled with electrochemical detection. Sensors 2008, 8 , 7097-7112. [CrossRef] [PubMed]

229. Li, H.; Tu, H.; Wang, Y.; Levine, M. Vitamin C in mouse and human red blood cells: An HPLC assay. Anal. Biochem. 2012, 426, 109-117. [CrossRef]

230. Vovk, T.; Bogataj, M.; Roskar, R.; Kmetec, V.; Mrhar, A. Determination of main low molecular weight antioxidants in urinary bladder wall using HPLC with electrochemical detector. Int. J. Pharm. 2005, 291, 161-169. [CrossRef]

231. Haswell, L.E.; Papadopoulou, E.; Newland, N.; Shepperd, C.J.; Lowe, F.J. A cross-sectional analysis of candidate biomarkers of biological effect in smokers, never-smokers and ex-smokers. Biomarkers 2014, 19, 356-367. [CrossRef] 
232. Wang, X.; Li, K.; Yao, L.; Wang, C.; Van Schepdael, A. Recent advances in vitamins analysis by capillary electrophoresis. J. Pharm. Biomed. Anal. 2018, 147, 278-287. [CrossRef]

233. Sun, X.; Niu, Y.; Bi, S.; Zhang, S. Determination of ascorbic acid in individual rat hepatocyte by capillary electrophoresis with electrochemical detection. J. Chromatogr. B Analyt. Technol. Biomed. Life Sci. 2008, 870, 46-50. [CrossRef]

234. Dong, S.; Zhang, S.; Cheng, X.; He, P.; Wang, Q.; Fang, Y. Simultaneous determination of sugars and ascorbic acid by capillary zone electrophoresis with amperometric detection at a carbon paste electrode modified with polyethylene glycol and $\mathrm{Cu}(2) \mathrm{O}$. J. Chromatogr. A 2007, 1161, 327-333. [CrossRef]

235. Zhao, S.; Huang, Y.; Liu, Y.M. Microchip electrophoresis with chemiluminescence detection for assaying ascorbic acid and amino acids in single cells. J. Chromatogr. A 2009, 1216, 6746-6751. [CrossRef]

236. Sun, X.; Niu, Y.; Bi, S.; Zhang, S. Determination of ascorbic acid in individual rat hepatocyte cells based on capillary electrophoresis with electrochemiluminescence detection. Electrophoresis 2008, 29, 2918-2924. [CrossRef]

237. Olędzka, I.; Kaźmierska, K.; Plenis, A.; Kamińska, B.; Bączek, T. Capillary electromigration techniques as tools for assessing the status of vitamins A, C and E in patients with cystic fibrosis. J. Pharm. Biomed. Anal. 2015, 102, 45-53. [CrossRef] [PubMed]

238. Georgakopoulos, C.D.; Lamari, F.N.; Karathanasopoulou, I.N.; Gartaganis, V.S.; Pharmakakis, N.M.; Karamanos, N.K. Tear analysis of ascorbic acid, uric acid and malondialdehyde with capillary electrophoresis. Biomed. Chromatogr. 2010, 24, 852-857. [CrossRef]

239. Huang, L.; Tian, S.; Zhao, W.; Liu, K.; Guo, J. Electrochemical vitamin sensors: A critical review. Talanta 2021, $222,121645$. [CrossRef]

240. Taleb, M.; Ivanov, R.; Bereznev, S.; Kazemi, S.H.; Hussainova, I. Graphene-ceramic hybrid nanofibers for ultrasensitive electrochemical determination of ascorbic acid. Mikrochim. Acta 2017, 184, 897-905. [CrossRef]

241. Hashemi, S.A.; Mousavi, S.M.; Bahrani, S.; Ramakrishna, S.; Babapoor, A.; Chiang, W.H. Coupled graphene oxide with hybrid metallic nanoparticles as potential electrochemical biosensors for precise detection of ascorbic acid within blood. Anal. Chim. Acta 2020, 1107, 183-192. [CrossRef] [PubMed]

242. Zhao, Y.; Qin, J.; Xu, H.; Gao, S.; Jiang, T.; Zhang, S.; Jin, J. Gold nanorods decorated with graphene oxide and multi-walled carbon nanotubes for trace level voltammetric determination of ascorbic acid. Mikrochim. Acta 2018, 186, 17. [CrossRef] [PubMed]

243. Liu, L.; Zhai, J.; Zhu, C.; Han, L.; Ren, W.; Dong, S. One-step synthesis of functional pNR/rGO composite as a building block for enhanced ascorbic acid biosensing. Anal. Chim. Acta 2017, 981, 34-40. [CrossRef]

244. Prasad, B.B.; Tiwari, K.; Singh, M.; Sharma, P.S.; Patel, A.K.; Srivastava, S. Molecularly imprinted polymer-based solid-phase microextraction fiber coupled with molecularly imprinted polymer-based sensor for ultratrace analysis of ascorbic acid. J. Chromatogr. A 2008, 1198-1199, 59-66. [CrossRef]

245. Karimi-Maleh, H.; Arotiba, O.A. Simultaneous determination of cholesterol, ascorbic acid and uric acid as three essential biological compounds at a carbon paste electrode modified with copper oxide decorated reduced graphene oxide nanocomposite and ionic liquid. J. Colloid Interface Sci. 2020, 560, 208-212. [CrossRef]

246. Asif, M.; Aziz, A.; Wang, H.; Wang, Z.; Wang, W.; Ajmal, M.; Xiao, F.; Chen, X.; Liu, H. Superlattice stacking by hybridizing layered double hydroxide nanosheets with layers of reduced graphene oxide for electrochemical simultaneous determination of dopamine, uric acid and ascorbic acid. Mikrochim. Acta 2019, 186, 61. [CrossRef]

247. Mehdi Motaghi, M.; Beitollahi, H.; Tajik, S.; Hosseinzadeh, R. Nanostructure electrochemical sensor for voltammetric determination of vitamin C in the presence of vitamin B6: Application to real sample analysis. Int. J. Electrochem. Sci. 2016, 11, 7849-7860. [CrossRef]

248. Eagle Biosciences. Vitamin C HPLC Assay. Available online: https://eaglebio.com/wp-content/uploads/data-pdf/vic31-h100 .pdf-package-insert.pdf (accessed on 23 November 2020).

249. Chromsystems. Vitamin C in Plasma/Serum-Automated HPLC. Available online: https://chromsystems.com/en/vitamin-cin-plasma-serum-automated-hplc-65765-f.html (accessed on 24 November 2020).

250. LeVatte, M.A.; Lipfert, M.; Zheng, J.; Wishart, D.S. A fast, sensitive, single-step colorimetric dipstick assay for quantifying ascorbic acid in urine. Anal. Biochem. 2019, 580, 1-13. [CrossRef] [PubMed]

251. Sigma-Aldrich. Ascorbic Acid Assay Kit II. Available online: https://www.sigmaaldrich.com/content/dam/sigma-aldrich/ docs/Sigma/Bulletin/1/mak075bul.pdf (accessed on 23 November 2020).

252. Biovision. Ascorbic acid colorimetric assay kit II (FRASC). Available online: https://www.biovision.com/documentation/ datasheets/K671.pdf (accessed on 23 November 2020).

253. Vislisel, J.M.; Schafer, F.Q.; Buettner, G.R. A simple and sensitive assay for ascorbate using a plate reader. Anal. Biochem. 2007, 365, 31-39. [CrossRef] [PubMed]

254. MyBiosource. Human vitamin C (VC) Elisa Kit (Competitive ELISA). Available online: https://cdn.mybiosource.com/tds/ protocol_manuals/000000-799999/MBS726748.pdf (accessed on 23 November 2020).

255. Cloud-Clone Corp. Elisa Kit for Vitamin C (VC). Available online: http://www.cloud-clone.com/manual/ELISA-Kit-forVitamin-C--VC--CEA913Ge.pdf (accessed on 23 November 2020).

256. Nováková, L.; Solich, P.; Solichová, D. HPLC methods for simultaneous determination of ascorbic and dehydroascorbic acids. Trends Analyt. Chem. 2008, 27, 942-958. [CrossRef] 
257. Tessier, F.; Birlouez-Aragon, I.; Tjani, C.; Guilland, J.C. Validation of a micromethod for determining oxidized and reduced vitamin C in plasma by HPLC-fluorescence. Int. J. Vitam. Nutr. Res. 1996, 66, 166-170.

258. Gao, X.; Zhou, X.; Ma, Y.; Qian, T.; Wang, C.; Chu, F. Facile and cost-effective preparation of carbon quantum dots for Fe3+ ion and ascorbic acid detection in living cells based on the "on-off-on" fluorescence principle. Appl. Surf. Sci. 2019, 469, 911-916. [CrossRef] 